\title{
Don't Jump on the Bandwagon: Negative Effects of Sharewashing
}

\author{
Adrian Lehr (D) - Marion Büttgen • Silke Bartsch
}

Accepted: 8 February 2021 / Published online: 18 March 2021

(C) The Author(s) 2021

\begin{abstract}
Access-based service usage, or simply "sharing", is an emerging consumption trend many companies pursue. As various firms seek to exploit this trend, however, consumers might not perceive these companies' services to be adequate, especially if they misleadingly present traditional marketplace exchanges (e.g., car renting) as sharing. This paper explores potential consequences of such forms of deceptive communication. Drawing on the concept of greenwashing and on consumer skepticism research, we introduce the concept of sharewashing, which we define as misleading communication that erroneously asserts a firm's offer as part of the sharing economy. To identify the underlying mechanism as well as the consequences of these deceptive practices, this research refers to three experimental studies. The results reveal negative effects of sharewashing on subsequent usage intentions, compared to both sharing and renting offers. Consumer skepticism mediates the effect between the type of offering and usage intention when a sharing offer is compared to a sharewashing offer, and it leads to lower perceived attractiveness and decreasing recipients' information seeking tendencies regarding the sharewashing offer. However, this mechanism does not hold true if a rental offer is compared
\end{abstract}

This paper was originally submitted and independently peer-reviewed at Business Research, one of SBUR's predecessor journals. It has been accepted by the same Editor-in-Chief for publication in the successor journal SBUR.

\footnotetext{
A. Lehr $(\bowtie) \cdot$ M. Büttgen

Chair of Corporate Management, Institute of Marketing \& Management, University of Hohenheim, Schwerzstr. 42, 70593 Stuttgart, Germany

E-Mail: a.lehr@uni-hohenheim.de

M. Büttgen

E-Mail: buettgen@uni-hohenheim.de

S. Bartsch

Institute for Marketing, Ludwig-Maximilians-University Munich, Ludwigstr. 28 RG, 80539 Munich, Germany

E-Mail: bartsch@bwl.lmu.de
} 
to a sharewashing offer, which indicates a different underlying mechanism. From the findings we derive several implications for companies and propose future research directions.

Keywords Attribution theory - Sharing economy · Access-based services · Carsharing $\cdot$ Sharewashing $\cdot$ Consumer skepticism · Deceptive communication · Deceptive advertising

\section{Introduction}

Novel consumption modes that do not involve transfer of ownership but instead provide access to physical goods for a limited period of time, such as car-sharing services, have recently expanded (Baumeister et al. 2015; Statista 2020). These consumption modes are known as sharing (Belk 2010) or access-based consumption (Bardhi and Eckhardt 2012). Forecasts predict the sharing economy's revenues to rise to $\$ 335$ billion globally by 2025 (Marchi and Parekh 2015), which makes this consumption trend increasingly important to corporate practice. It can also help companies improve their image, largely because consumers generally regard such offers as flexible, innovative, and forward-thinking (Belk 2014b; Baumeister et al. 2015).

While there is a considerable amount of literature on the underlying consumer motivations to use access-based services (e.g., Bardhi and Eckhardt 2012; Lamberton and Rose 2012; Möhlmann 2015; Lawson et al. 2016; Schaefers et al. 2016a), research has neglected the potential dark sides of this consumption trend, such as a potential misuse by companies seeking to exploit this trend to achieve positive image effects without providing the features that consumers expect from accessbased services (e.g., convenience, high flexibility, short-term access to products). Price and Belk (2016) denounce firms' efforts to tout regular marketplace exchanges formerly known as rental offers, as sharing, simply by labeling traditional renting services as "sharing," which is a growing phenomenon in practice (see also Gheorghe 2017; taz 2017). Various companies, such as app2drive or Cambio, claim to offer carsharing services without exhibiting the main characteristics of a car-sharing service, i.e., being temporally and locally flexible regarding car pick-up and return.

Based on these explanations and derived from the concept of greenwashing, which is defined as misleading claims about environmental practices (Nyilasy et al. 2014; Walker and Wan 2012), we call misleading behaviors regarding sharing sharewashing. Thus, we define sharewashing as companies' activities that intentionally mislead consumers with deceptive claims, falsely presenting the firm as part of the sharing economy. Table 1 offers an overview of distinctive characteristics of car-sharing, renting, and sharewashing.

In "real" car-sharing, registered consumers can unlock a car via a smartphone app and instantly use the service without pre-booking or defining their consumption time in advance. In contrast, consumers using a traditional car rental service need to book a fixed consumption time beforehand, and pick up and drop off the car at specific car rental premises (Benoit et al. 2017). Although rental and sharing partially overlap, 
Table 1 Characteristics of car-sharing, rental, and sharewashing offers

\begin{tabular}{|c|c|c|c|}
\hline & Car-sharing offer & Rental offer & Sharewashing offer \\
\hline $\begin{array}{l}\text { Communication } \\
\text { of offer }\end{array}$ & $\begin{array}{l}\text { Communicated } \\
\text { as car-sharing } \\
\text { offer }\end{array}$ & Communicated as rental offer & $\begin{array}{l}\text { Communicated as car-shar- } \\
\text { ing offer }\end{array}$ \\
\hline $\begin{array}{l}\text { Point in time } \\
\text { for pick-up \& } \\
\text { return }\end{array}$ & $\begin{array}{l}\text { Flexible (no } \\
\text { predefined time } \\
\text { frame) }\end{array}$ & $\begin{array}{l}\text { Fixed (i.e., predefined time } \\
\text { frame, high penalty for over- } \\
\text { due returns) }\end{array}$ & $\begin{array}{l}\text { Fixed (i.e., predefined time } \\
\text { frame, high fees for overdue } \\
\text { returns) }\end{array}$ \\
\hline Period of use & $\begin{array}{l}\text { Shorter con- } \\
\text { sumption time }\end{array}$ & Longer consumption time & Longer consumption time \\
\hline $\begin{array}{l}\text { Location of } \\
\text { pick-off \& } \\
\text { return }\end{array}$ & $\begin{array}{l}\text { Flexible (e.g., } \\
\text { predefined city } \\
\text { areas) }\end{array}$ & $\begin{array}{l}\text { Fixed (e.g., at predefined } \\
\text { stations) }\end{array}$ & $\begin{array}{l}\text { Fixed (e.g., at predefined } \\
\text { stations) }\end{array}$ \\
\hline
\end{tabular}

Based on: Belk (2014a, 2014b), Benoit et al. (2017); CarClub (2018), Moeller and Wittkowski (2010)

the concept of sharing with its innovative business models (Baumeister et al. 2015; Andreassen et al. 2018) and extreme flexibility in sharing offers involves a different consumption paradigm (Belk 2014b; Price and Belk 2016).

The literature on access-based services barely addresses this topic of deceptive advertising. Thus, a deeper understanding of the consequences of misleading communication can help companies anticipate individual consumer responses to such a strategy. Particularly, some companies inaccurately assert an offer is based on a sharing concept to make it appear more attractive. Such attempts to increase consumers' use of their service could have negative consequences. To address the abovementioned gap in theoretical and managerial knowledge, we investigate the effects of deceptive communication about access-based services, i.e., sharewashing, on consumer attitudes and behavioral intentions relative to communication about both real sharing offers and traditional rental offers. Specifically, we analyze the effects on consumers' passive interest (in terms of perceived attractiveness) and active interest (in terms of information seeking) and on their subsequent usage intention. Further, to disclose the underlying mechanism, we consider whether consumer skepticism mediates the relationship between sincere or deceptive communication regarding the service and the attitudinal and behavioral outcomes.

Our research is grounded in attribution theory (Kelley and Michela 1980), which suggests investigating the causal explanations people give when they confront others' behaviors (Weiner 2000). The theory provides an appropriate framework for understanding how consumers process misleading communication. We combine these insights with the concepts of consumer skepticism and greenwashing to contribute to current research in several ways.

First, we advance the literature pertaining to access-based services by introducing the concept of sharewashing as a new form of deceptively communicating a service. While deceptive communication research has mainly focused on firms communicating about their CSR and on the negative effects of greenwashing, we show that it can arise in other contexts as well. For example, such deception occurs when companies attempt to exploit a new consumption trend by entering a market with misleading communication about their service. We provide evidence for the generalizability of this deceptive communication concept and its consequences. 
Second, we contribute to research on consumer skepticism in deceptive communication contexts. Our results reveal different underlying mechanisms leading to lower usage intentions for sharewashing offers. While consumer skepticism mediates the effect of sharewashing (compared to real sharing) on usage intention, in that skepticism is higher toward sharewashing than toward real sharing, this mechanism does not hold true for the comparison of rental and sharewashing offers. Hence, entering a highly dynamic and increasingly changing market with a traditional car rental offer can also cause consumer skepticism, but still leads to higher usage intention. This indicates a parallel mechanism that is based on the mere-exposure effect and familiarity with such a traditional market offer and mitigates the negative effect of consumer skepticism on usage intention.

Third, from a more theoretical perspective, we contribute to attribution theory by identifying a mediating mechanism that explains usage decisions in the context of misleading communication regarding services. Our focus is not the attribution process itself. Rather, we highlight a downstream effect of how active and passive interest, resulting from attributions and expressed in response to honest versus deceptive communication, determine subsequent usage likelihood.

To these ends, the paper is structured as follows. First, we provide a short literature review on findings related to access-based services and consumer skepticism, and introduce attribution theory as our theoretical foundation. On this basis, we derive hypotheses and develop a conceptual framework for investigating how misleading communication about services impacts consumer perceptions and intentions. Subsequently, we present three empirical studies and discuss the results, along with their research contributions and implications for business managers. Finally, we note some limitations and directions for further research.

\section{Literature Review and Research Model}

Our literature review revealed that previous research on access-based services has focused mainly on the individual drivers of and barriers to access-based consumption. Most consumers participate for utilitarian reasons, such as monetary advantage, flexibility, or convenience (Bardhi and Eckhardt 2012; Hamari et al. 2016; Hazée et al. 2017; Lamberton and Rose 2012; Lawson et al. 2016; Möhlmann 2015; Moeller and Wittkowski 2010). Further, research affirms that companies that introduce access-based services are perceived as more innovative and forward-thinking (Belk 2014b; Baumeister et al. 2015). To shed light on the positioning of accessbased service providers, Wruk et al. (2019) analyze value propositions and business model features promoted by selected organizations and identify different legitimation strategies. Considering that more and more companies seek to join the sharing trend, there is also an increasing need to clarify what happens when organizations jump on the bandwagon and misleadingly promote their service as a sharing service with the sole aim of achieving positive image effects. Such companies' offers do not have the features typically associated with sharing.

Although various articles on access-based services draw implications for marketing communication (e.g., Ertz et al. 2017; Hazée et al. 2017; Fritze et al. 2020; 
Peterson and Simkins 2019), to our knowledge Costello and Reczek (2020) are the only one that empirically investigate how access-based services are communicated and how such communication impacts consumer-related variables (see Table 2). Costello and Reczek (2020) show that, compared to platform-focused communication, provider-focused communication increases consumers' willingness to pay and the likelihood that they will purchase or download a brand's app. Interestingly, so far no empirical research has investigated the effects of deceptive communication of access-based services, despite the fact that Belk (2014a, b) already emphasized the relevance of "pseudo-sharing (practices masquerading as sharing)" (Belk 2014a, p. 10).

This prompted us to extend our literature review to include research on misleading communication and deceptive advertising. Considerable research on deceptive advertising has been conducted on CSR and green advertising, revealing that firms' underlying motivations influence consumers' perceptions. Previous work shows that egoistic or profit-oriented motives for green claims lead to mistrust and skepticism (Skarmeas and Leonidou 2013); green advertising combined with poor environmental performance leads to a backlash, including elevated skepticism accompanied by diminished attitudes toward the firm and reduced purchase likelihood (Nyilasy et al. 2014). In the context of green advertising, consumer skepticism refers to a tendency to disbelieve or doubt the accuracy of marketing communication (Skarmeas and Leonidou 2013; Obermiller and Spangenberg 1998; Forehand and Grier 2003; Wanner and Janiesch 2019). Our research expands on the notion of misleading advertising about environmental effects, that is, greenwashing. Doing so, we propose that consumer skepticism can similarly result from misleading communication by companies that tout their fake access-based services, a practice we call sharewashing. Thereby we examine the greenwashing concept's transferability to a new and different context.

To date, literature on access-based services addresses consumer skepticism merely in relation to hygienic or environmental concerns (Hazée et al. 2019; Gullstrand Edbring et al. 2016). We want to close the identified gap and shed light on the dark side of access-based services, i.e., jumping on the bandwagon of access-based services and deceptively masking a traditional (rental) offer as a car-sharing offer. Table 2 provides an overview of previous research on access-based services, which investigates or at least addresses one of the topics of marketing communication, deceptive communication, or consumer skepticism.

To understand the consequences of this specific type of deceptive advertising, which we define as consumer-perceived sharewashing, we have chosen attribution theory as the overarching theoretical framework. Attribution theory describes the causal inferences people rely on to explain their own or others' behavior (Brosi et al. 2018; Heider 1944; Kelley 1973; Kelley and Michela 1980). In marketing literature, this theory has served to explain responses to product failures (Klein and Dawar 2004), consumer skepticism (Rifon et al. 2004; Skarmeas and Leonidou 2013), and the effects of greenwashing (Nyilasy et al. 2014). Accordingly, attribution theory is likely to explain how consumers interpret a company's communication if it takes the form of sharewashing. 


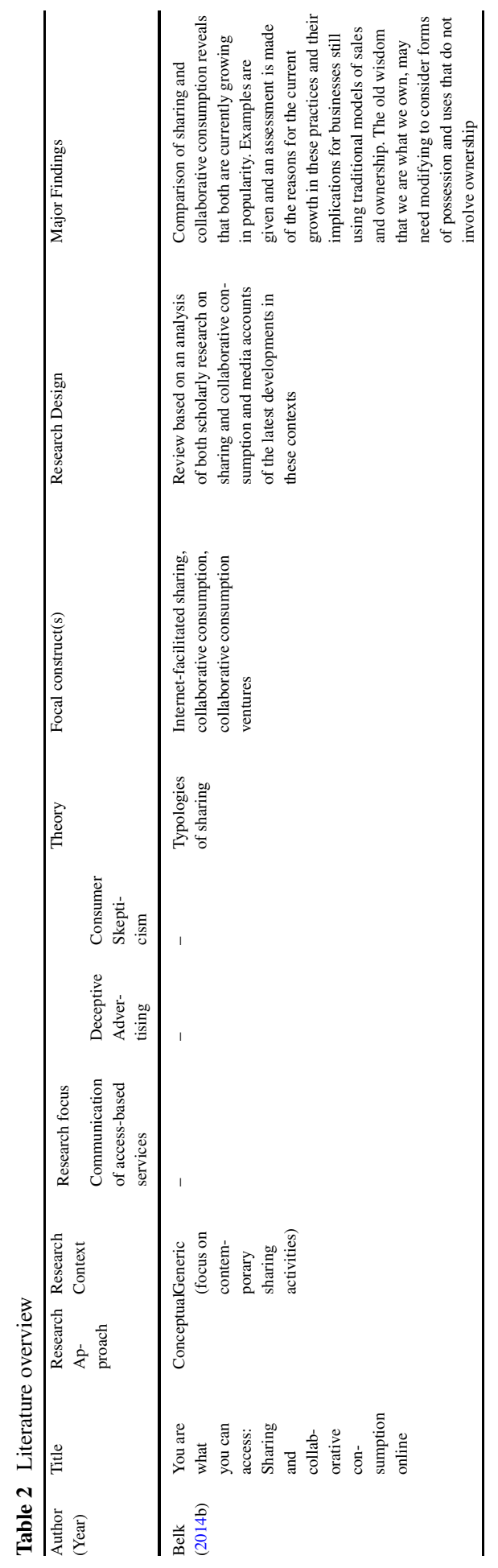




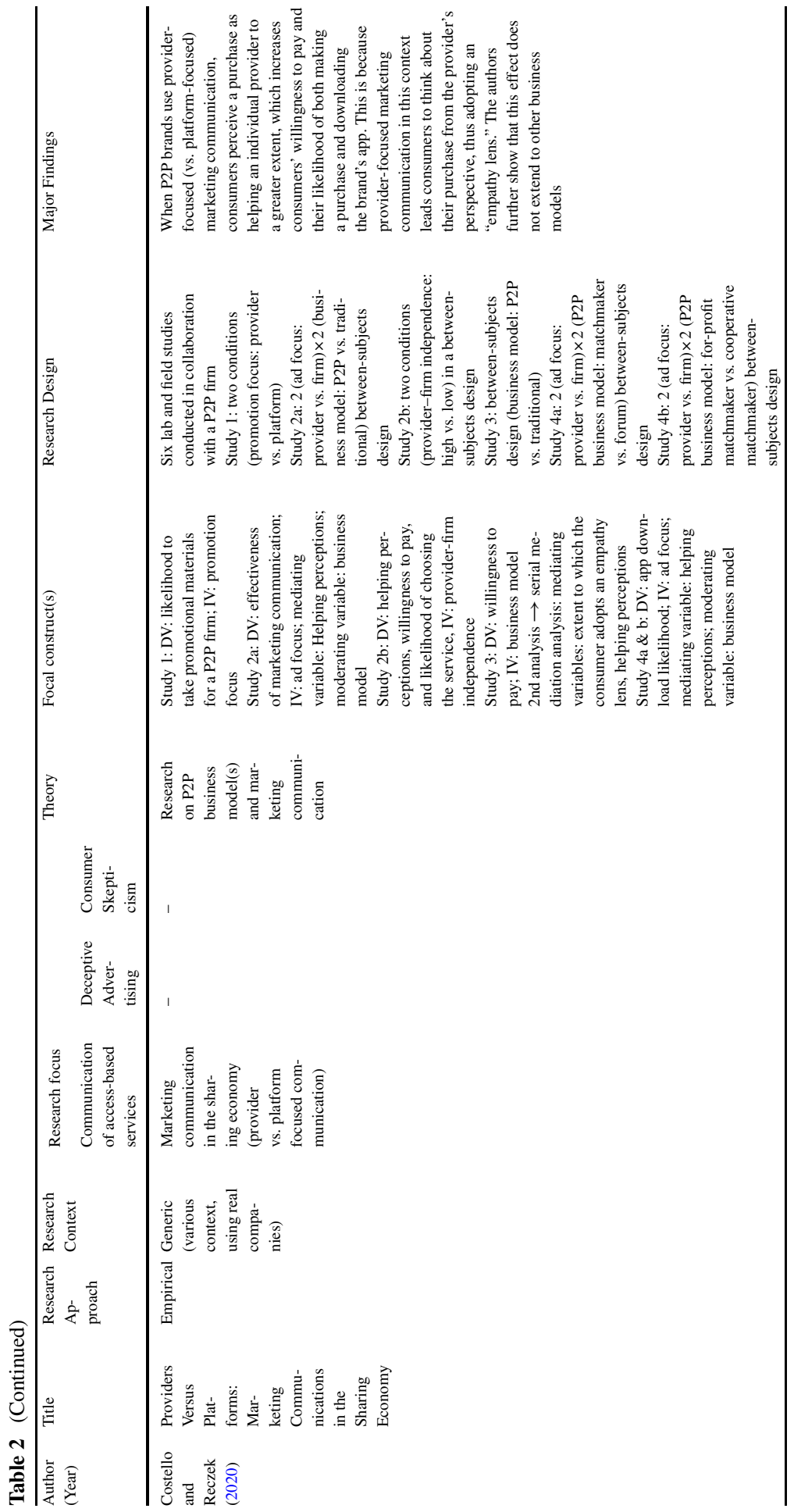




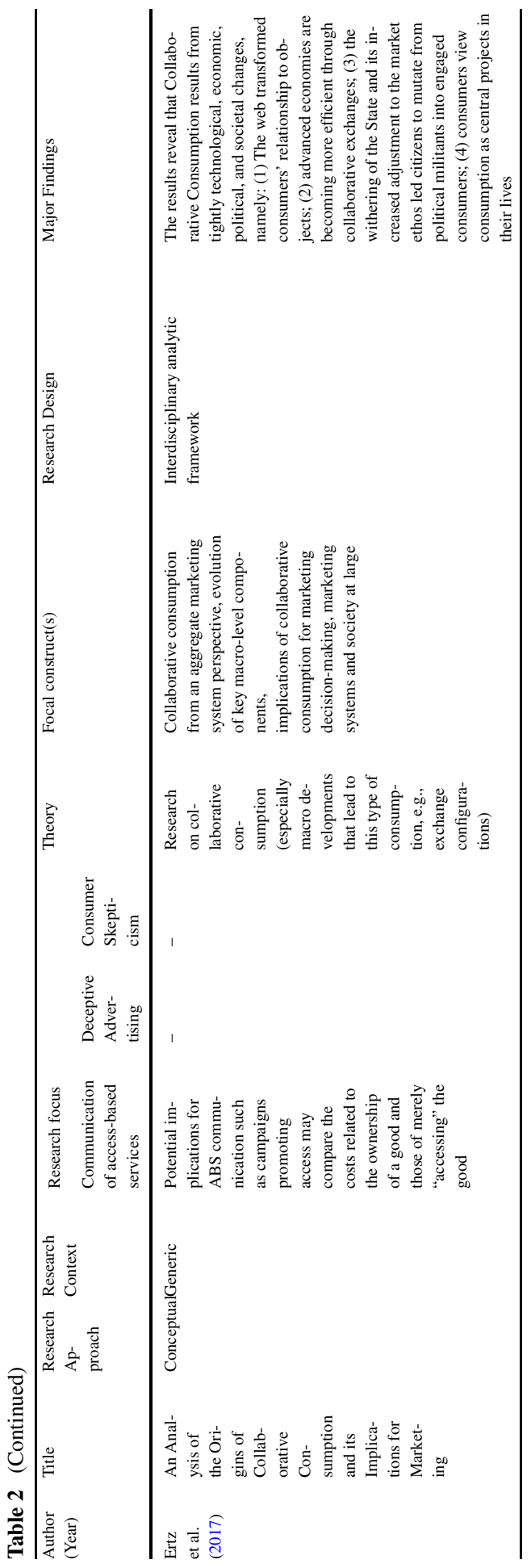




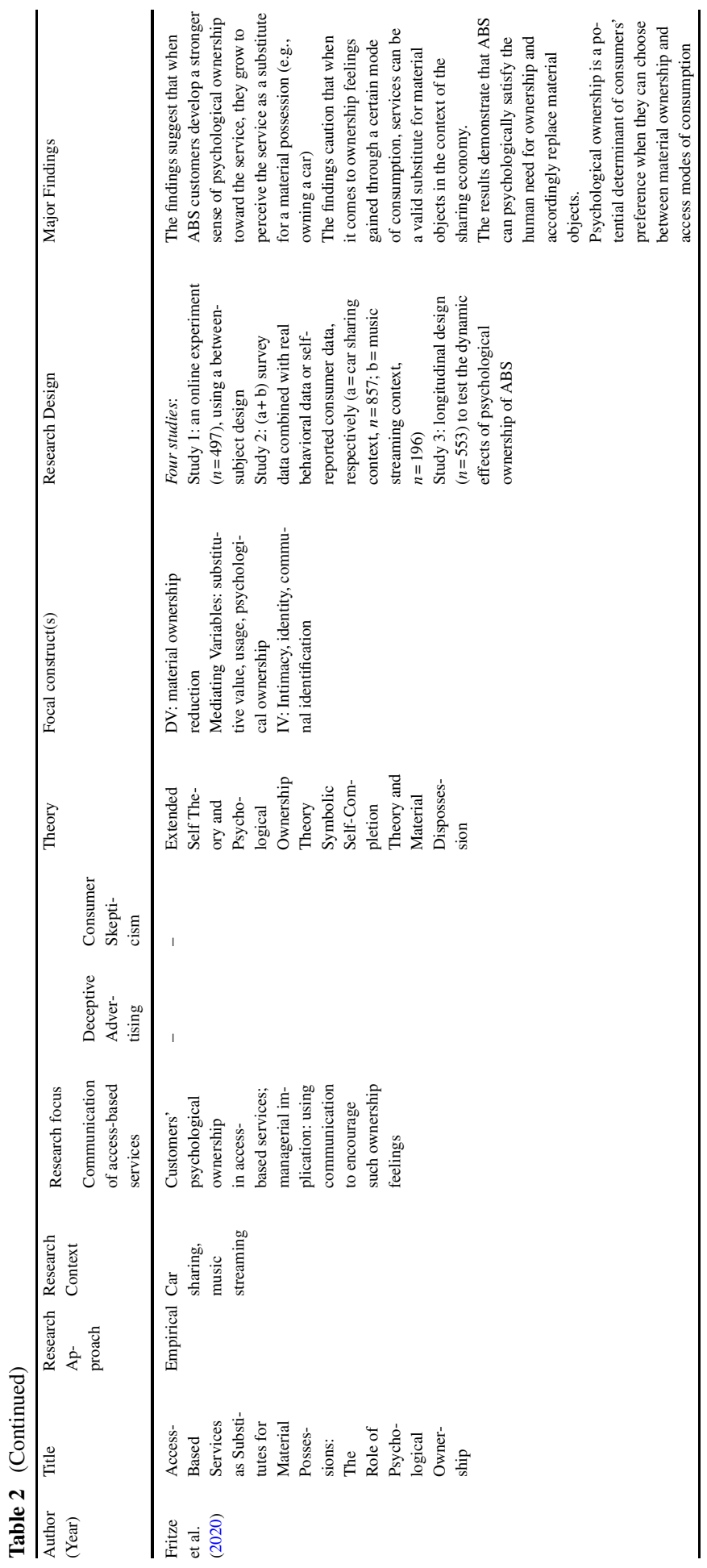




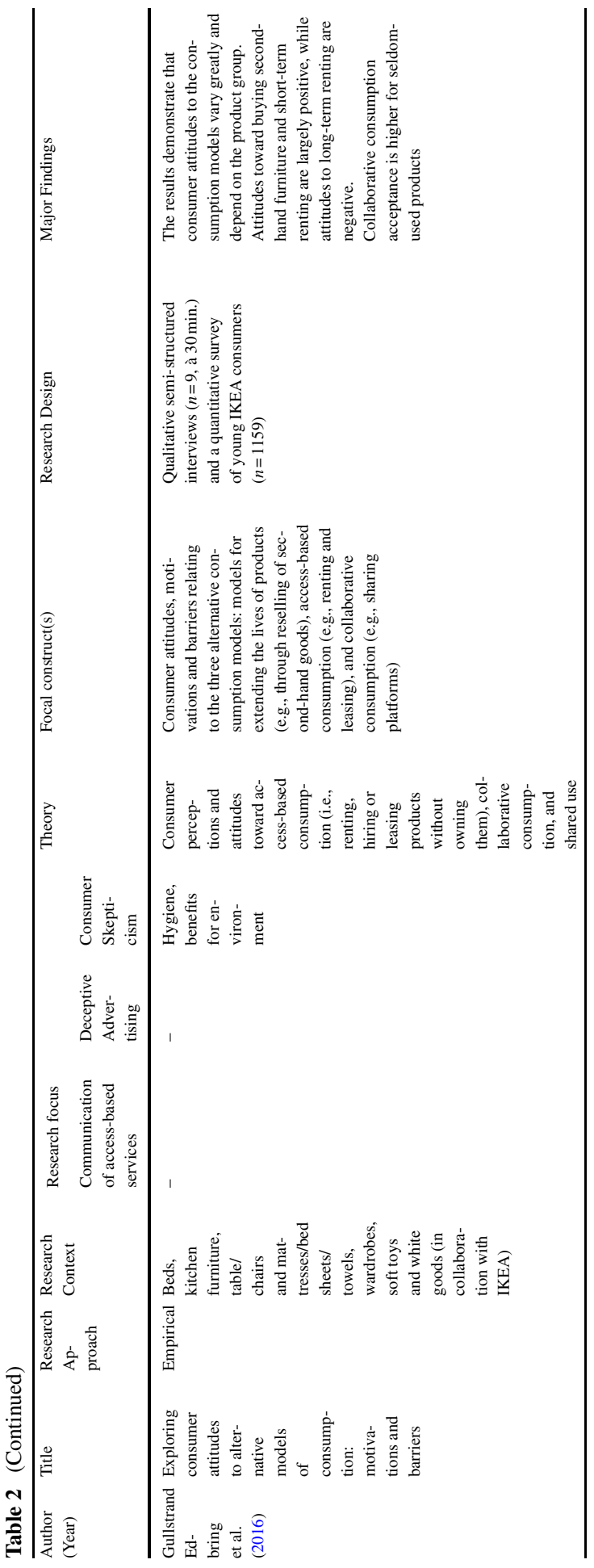




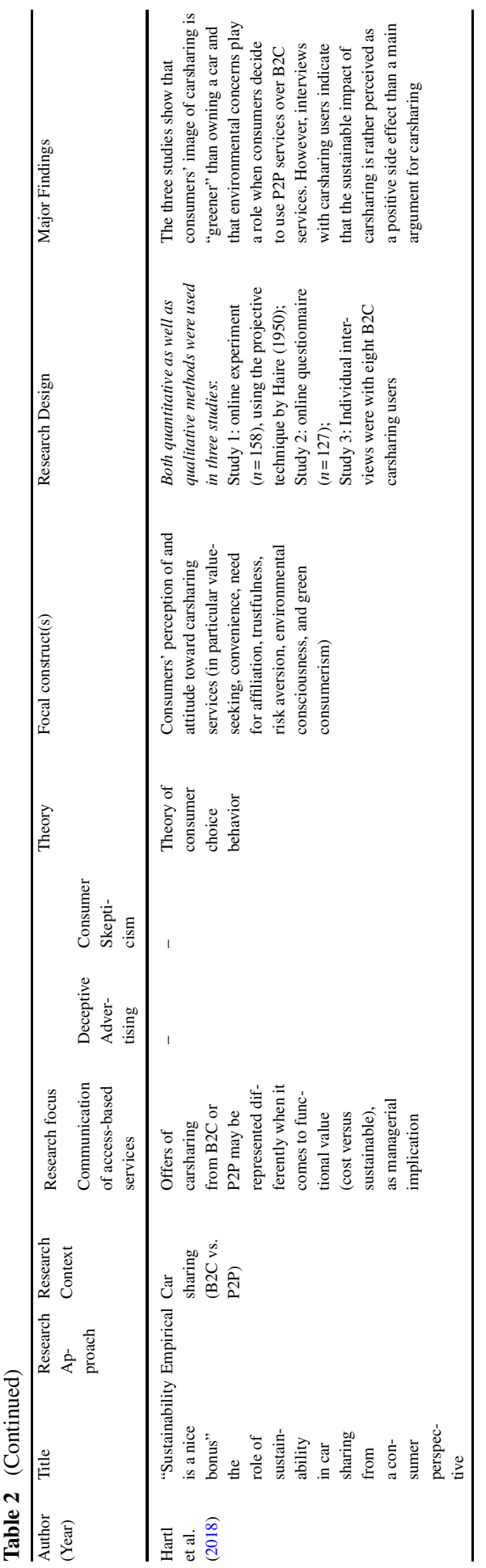




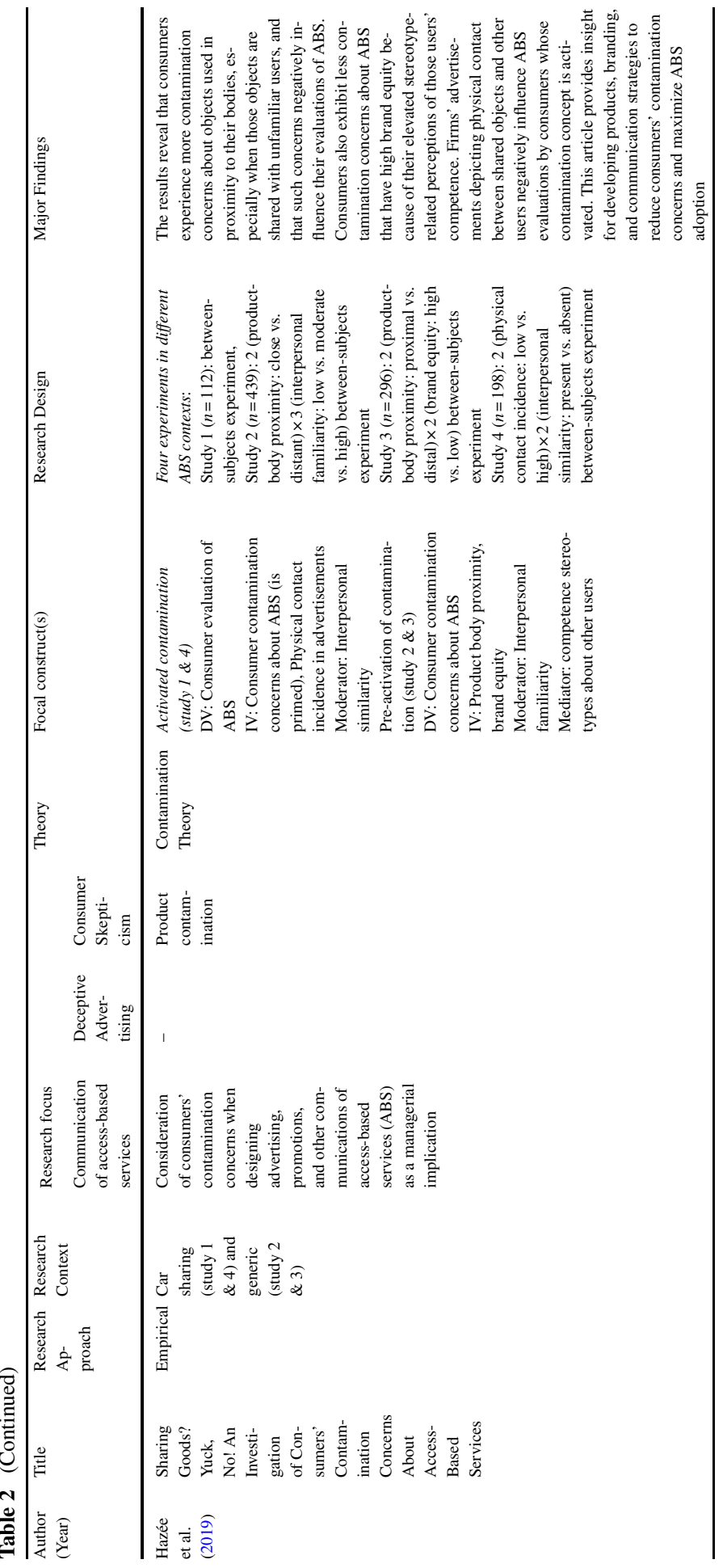




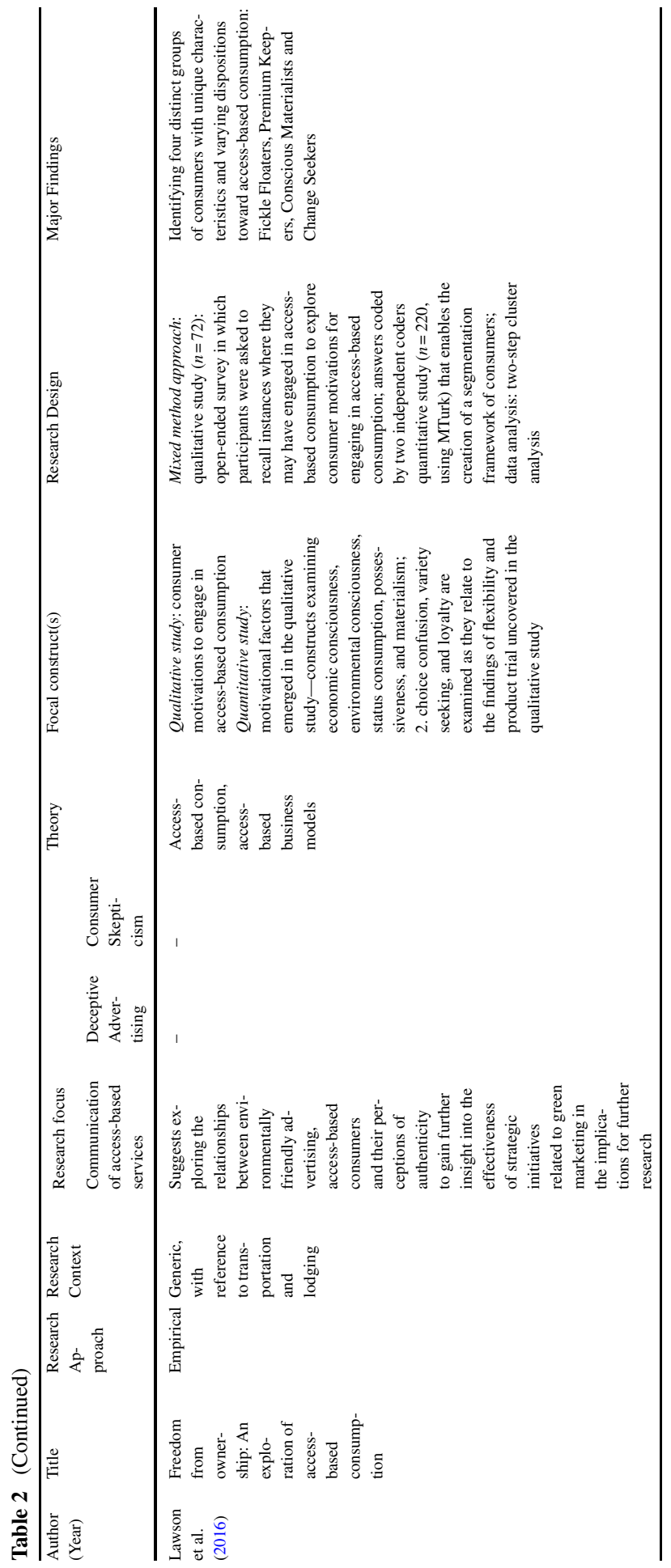




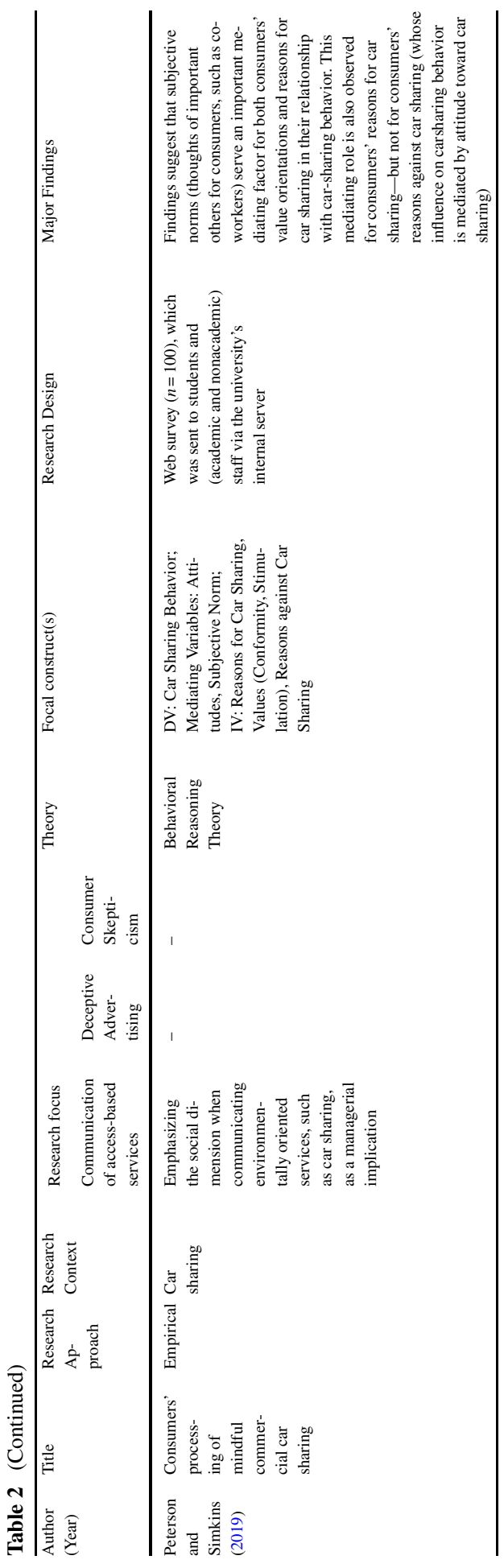




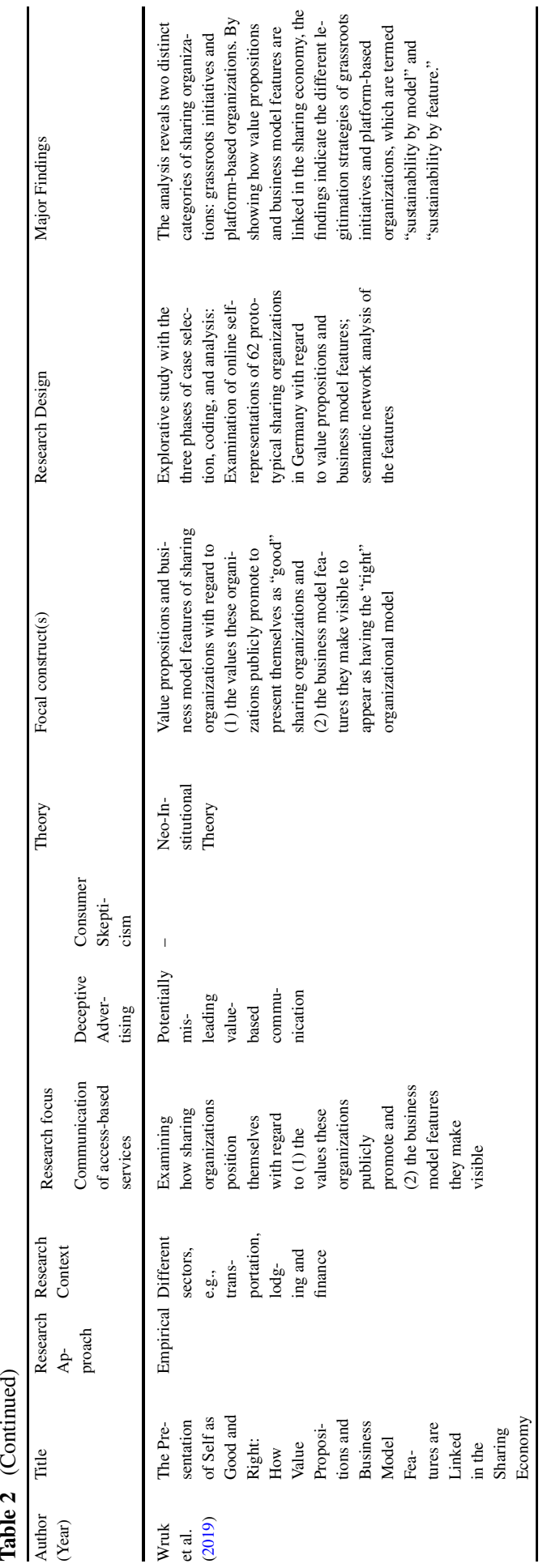




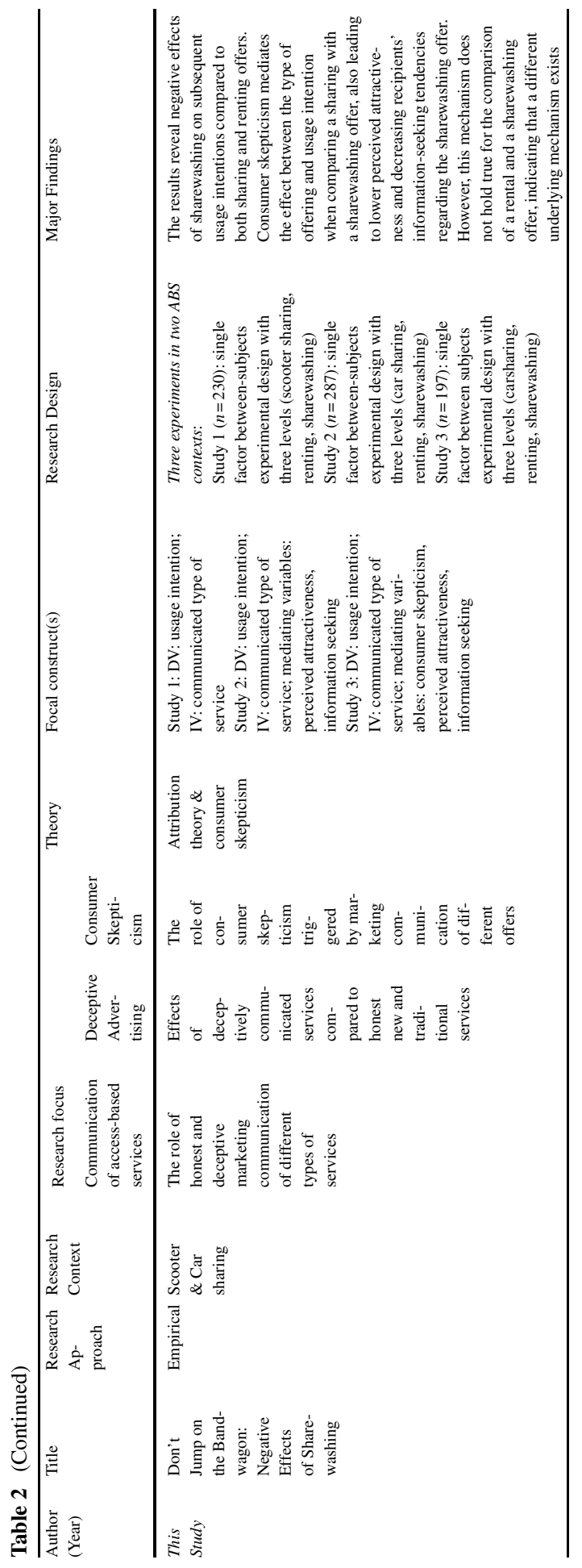


According to Heider's (1944) framework, consumers ascribe two kinds of motives to corporate actions: intrinsic or extrinsic ones (Leonidou and Skarmeas 2017; Parguel et al. 2011). Intrinsic motives serve the wider public, while extrinsic motives serve the firm and include an opportunistic element (Leonidou and Skarmeas 2017; Skarmeas and Leonidou 2013; Romani et al. 2016). The two kinds of motives can also coexist (Ellen 2006). Stronger attributions of intrinsic motives, that is, the willingness to serve a wider public, lead consumers to react positively toward the company. In contrast, predominantly extrinsic motives, associated with the company's sole intention to increase company profits or other business returns, lead to less favorable attitudinal and behavioral responses (Romani et al. 2016). When consumers receive accurate messages about companies introducing a real sharing offer, they might regard these messages as signaling the firms' genuine, intrinsically motivated effort to adopt the sharing economy's values, consistent with altruistic behavior (Field et al. 2018), such as resource conservation. If instead, companies spuriously label their offerings as sharing even when they provide nothing more than a traditional market exchange (e.g., renting), consumers might perceive it as opportunistic, selfish, and untrustworthy behavior demonstrating extrinsic motives. Such firms might appear to be jumping on the bandwagon of the car-sharing trend just to grow their business. Previous research demonstrates that perceptions of such extrinsic motivation generate skepticism (Leonidou and Skarmeas 2017). We depict the relationships between the communicated type of service and all other relevant constructs in a conceptual model (see Fig. 1).

In line with this reasoning, people's tendency to use the service should increase if a firm introduces a service that is consistent with the sharing economy's values and with collaborative consumption ideals. However, communicative instruments perceived as opportunistic and extrinsically motivated could instead prompt consumer skepticism and can backfire. Then, similarly to greenwashing, such communication reduces consumers' intention to use the offer (Nyilasy et al. 2014; Leonidou and Skarmeas 2017). Since skepticism toward an advertisement decreases purchase intention (Chang and Cheng 2015), we assume that consumers will not only favor true car-sharing offers, but also directly communicated, true rental offers over sharewashing offers. Overall, we posit that this misleading communication strategy has negative consequences for companies that decide to talk the talk without walking the sharing economy walk. These negative effects ultimately might be more harmful than an honest attempt at marketing a classical service (e.g., traditional rental), which would not evoke consumer skepticism in the same way. Thus, we propose:

H1 A sharewashing offer leads to lower usage intention than (a) a car-sharing offer, or (b) a traditional car rental offer.

Besides this direct effect, we also investigate mediating mechanisms that could explain purchase decisions in this context. This includes investigating how honest and dishonest communication affects consumers' active and passive interest in using the service. Therefore, next, this research investigates how the communicated type of service affects an offer's attractiveness and consumers' information seeking tendency. In particular, attractiveness refers to an overall assessment of a product or 


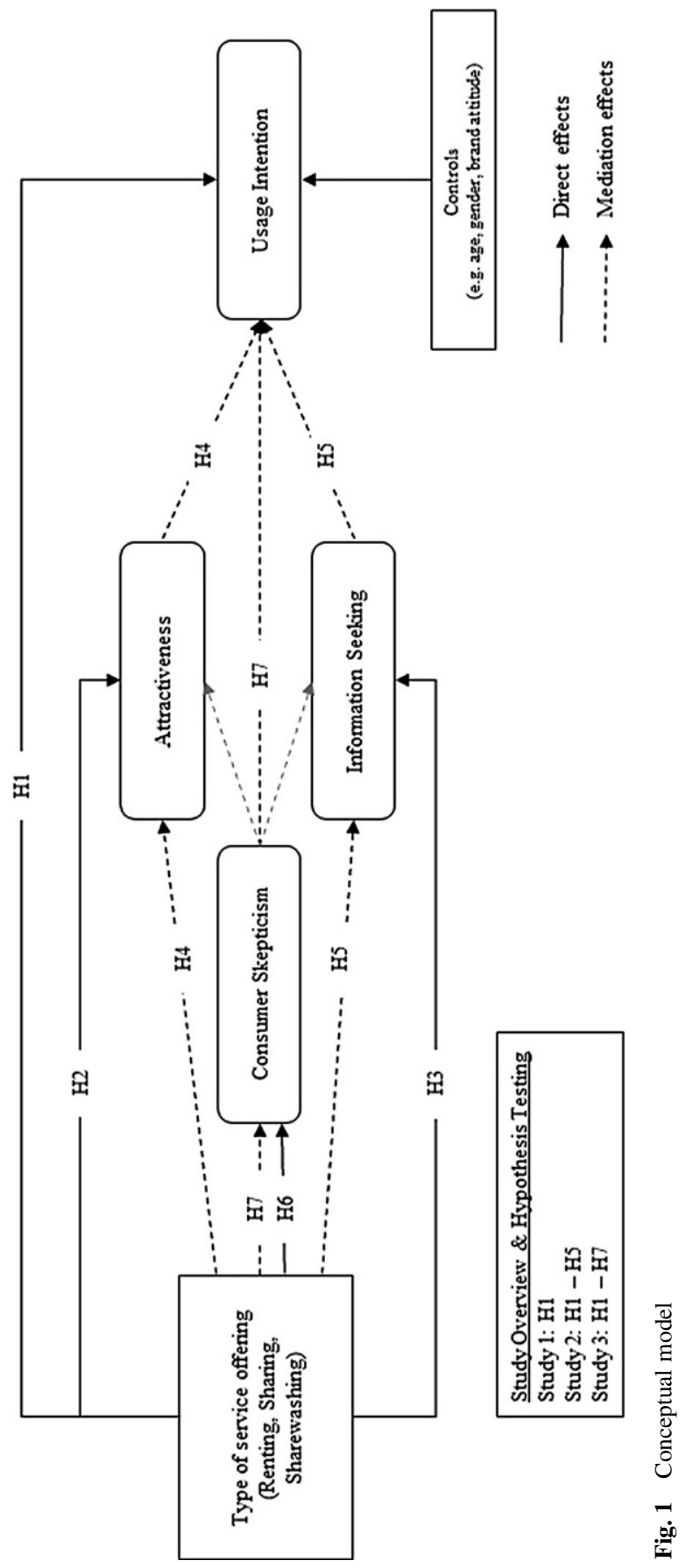


brand (Boyd and Mason 1999), which can be interpreted as a kind of passive interest in an offer. Perceptions of attractiveness are likely to reflect consumers' views on the extrinsic and intrinsic motives companies have in their communication: intrinsically motivated offers would appear to be authentic, honest, and thus attractive (Leonidou and Skarmeas 2017; Parguel et al. 2011); extrinsically motivated offers, i.e., sharewashing, would not (Nyilasy et al. 2014; Leonidou and Skarmeas 2017). Further, we consider perceived attractiveness to be indicative of consumers being likely to adopt new and innovative products (Boyd and Mason 1999), which is particularly interesting when companies enter a market with new offers. Hence, we assume that an honestly communicated service would increase the attractiveness of the offer, while deceptive communication would be perceived as a tactic to enter the market, thereby decreasing the offer's perceived attractiveness. As proposed previously, we suggest that honestly communicating a traditional rental service in a market entry situation would not be as harmful as sharewashing, because it does not evoke the impression of an extrinsically motivated company trying to trick the consumer. Thus, we hypothesize:

H2 A sharewashing offer is perceived as less attractive by consumers than (a) a carsharing offer, or (b) a traditional car rental offer.

Next, information seeking refers to consumers' active interest, manifested as searching for additional information about a particular offer (Ruvio and Shoham 2007; Dholakia 2001). Attribution theory suggests that intrinsically motivated firm actions, including accurate communication about authentic sharing efforts, enhance consumers' evaluation of the firm and its offerings (Leonidou and Skarmeas 2017; Parguel et al. 2011), which in turn should prompt positive reactions. Thus, consumers who find an offer appealing start searching for information (Dholakia 2001). Contrastively, misleading, extrinsically motivated communication will evoke consumer skepticism and refusal. For this study, we consciously diverge from claims by Leonidou and Skarmeas (2017) who investigated information seeking in the context of greenwashing. They conceptualized information seeking as specific search and scrutinizing behavior to verify doubts related to a product's environmental attributes. In contrast to their study, we conceptualize information seeking as an interest-based construct arising from a deep personal involvement in the purchase decision to gain expertise (de Bruyn and Lilien 2008). Accordingly, in this study information seeking does not refer to an attribute-based information seeking behavior, but to a holistic search that shows interest (Ruvio and Shoham 2007) in collecting more knowledge about the offer in general. Hence, we postulate:

H3 A sharewashing offer leads to less information seeking by consumers than (a) a car-sharing offer, or (b) a traditional car rental offer.

Since information seeking (i.e., an active behavioral facet of consumers' interest) is considered integral to purchase decisions and associated with greater purchase tendencies (Demirgunes and Avcilar 2017; Kiel and Layton 1981; Newman and 
Staelin 1972), we presume the same for attractiveness (i.e., a passive attitudinal facet of consumers' interest).

In line with the first hypothesis, and consistent with attribution theory, consumers who encounter extrinsically motivated, disingenuous communication might even develop views that diminish the attractiveness of the offer and constrain their desire to seek information about it. Consumer skepticism can evoke negative perceptions of the company and its product (Kirmani 2011). Compared to communication about both sharing and traditional rental offers, sharewashing is assumed to negatively influence consumers' usage intention due to them perceiving the offer to be less attractive (passive interest) and, therefore, restricting their information seeking (active interest). Thus, we hypothesize:

H4 Comparing a sharewashing offer to (a) a car-sharing offer, or (b) a traditional car rental offer, the negative effect of sharewashing on usage intention is mediated by the consumers' perceived attractiveness of the service.

H5 Comparing a sharewashing offer to (a) a car-sharing offer, or (b) a traditional car rental offer, the negative effect of sharewashing on usage intention is mediated by the consumers' intention to seek information on the service.

Following here, we focus on the underlying mechanism of consumer skepticism, that is supposed to be causal in consumers' perceptions and usage intentions when they encounter a company's offer of a new service. While some research considers consumer skepticism to be a rather stable belief or personality trait (Obermiller and Spangenberg 1998), other research shows skepticism to be situational, e.g., provoked by inconsistent and misleading marketing communication (Connors et al. 2017; Skarmeas and Leonidou 2013). In the case of sharewashing, a company can claim to offer, e.g., a car-sharing service without displaying the service's specific sharing features. According to attribution theory, such a deceptive, extrinsically motivated communication of a service will trigger consumer skepticism, while an accurately communicated car-sharing or a real rental offer will not do so. Hence, we postulate:

H6 A sharewashing offer leads to higher consumer skepticism than (a) a carsharing offer, or (b) a traditional car rental offer.

Once consumers recognize a company's activity as being opportunistic and extrinsically motivated, even as deceptive, their perceptions and behaviors, including their intentions to adopt or use the service (Grewal et al. 1998; Yin et al. 2016) are likely to be negatively affected. Similar to what happens in the case of greenwashing, consumer skepticism can be provoked and can backfire in reducing consumers' purchase or use intention (Nyilasy et al. 2014; Leonidou and Skarmeas 2017). Since skepticism toward advertising decreases purchase intention (Chang and Cheng 2015), we presume that consumers will favor correctly communicated, rental or sharing offers above deceptive sharewashing. Thus, we hypothesize: 
H7 Comparing a sharewashing offer to (a) a car-sharing offer, or (b) a traditional car rental offer, the negative effect of sharewashing on usage intention is mediated by consumer skepticism toward the service.

\section{Overview of Studies}

To test our prediction that sharewashing has a negative impact on consumers' perceptions, and hence, on the companies that use a misleading communication strategy in trying to introduce their services, we conducted three experiments. We used a stepwise approach, which is common in consumer behavior research (e.g., Wu et al. 2017), to investigate the effects of the sharewashing phenomenon. Hence, Study 1 examines the basic question on whether sharewashing negatively affects consumers' willingness to use or purchase the new offer. To better understand the downstream effect of sharewashing, Study 2 analyzes the mediating effects of the offer's perceived attractiveness to consumers, and of their information seeking behavior. Finally, Study 3 sheds light on the underlying psychological process that causes less active and passive interest as well as lower usage intentions for sharewashing offers. Accordingly, we investigated consumer skepticism as a further mediator and its role as causal mechanism. In analyzing the results of these studies, we tested all the hypotheses postulated above.

\subsection{Study 1}

Study 1 provides an initial investigation of the effect sharewashing has on the intention to use a new service a company issues.

\subsubsection{Research Design and Sample}

To test our hypothesis, we applied a between-subjects experiment with one independent variable on three levels. We created appropriate stimulus material in the form of different communication stimuli that described sharing e-scooters (i.e., electrified motor scooters; see Appendix 1). One stimulus reflected the true sharing condition, in that the stimulus described a highly flexible, free-floating concept that shows a real-world e-scooter sharing offer by stella-sharing. However, we changed the brand name in our experiment. In a second stimulus reflecting a traditional rental offer, we used a description of a more traditional bike rental service. Finally, a third stimulus represented the sharewashing communication strategy by providing information similar to the rental description, but it consistently used the term "sharing" in the header and in descriptions. All three treatments were presented as new offers of the mobility service provider Deutsche Bahn.

Email invitations and survey links to our study were sent through blogs, social media groups, and university mailing lists in Germany. Thus, we invited participants to our study without any specific preselection. We used all available online channels to spread the link. We assigned the participants to one of the experimental groups using a random assignment mechanism in the survey tool Unipark. Respondents 
Fig. 2 Mean plot of usage intention-Study 1

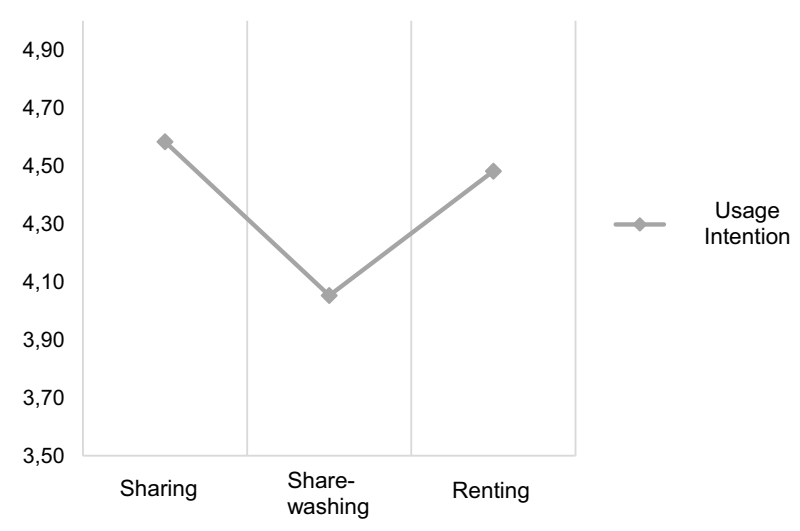

were directly informed that their participation was voluntary and that they could withdraw at any point during the survey. They were assured that all information they gave would be anonymized to protect their identities, and that analyses would only be conducted on the aggregate level. Further, we included a manipulation check: "This advertorial relates to a sharing offer" for the sharing scenario, and "The offer in the advertorial is presented as a sharing offer" for the sharewashing scenario. Additionally, we inserted an attention check at the beginning of the survey to ensure respondents' careful attention (Estes et al. 2018). For this we asked whether the presented stimulus communicated a service about an e-scooter. The initial raw data sample comprised 250 respondents. Participants who failed to pass these checks were excluded. The final sample thus consisted of 230 participants, relatively equally distributed across the three scenarios of sharing $(N=69)$, sharewashing $(N=80)$, and traditional renting $(N=81)$. The respondents were between the ages of 19 and 55 (26 years old on average) and most were women (65\%).

\subsubsection{Measure}

To measure our dependent variable, we employed a seven-point Likert scale based on Grewal et al. (1998). Usage intention was captured with items such as "My willingness to use this offer is very high." The scale was highly reliable $(\alpha=0.893)$, exceeding the generally accepted threshold of 0.70 for Cronbach's alpha (Hair 2010).

\subsubsection{Results}

To test H1, we conducted an analysis of variance (ANOVA) with usage intention, which revealed significant main effects of the three manipulations $(F(2,22)=3.291$, $p<0.05)$ on consumers' intention to use the service. With follow-up univariate ANOVAs, we investigated individual effects between treatments. As postulated, respondents who read the sharewashing stimulus indicated significantly lower intention to use the new offer than those who encountered a sincere communication message about the sharing offer $(\mathrm{H} 1 \mathrm{a})\left(\mathrm{M}_{\text {sharewashing }}=4.05, \mathrm{M}_{\text {sharing }}=4.58 ; \mathrm{F}(1,147)=5.10\right.$, $p<0.05)$ or a communication stimulus describing the traditional renting offer $(\mathrm{H} 1 \mathrm{~b})$ 
Table 3 Post hoc test-Study 1

\begin{tabular}{llllllll}
\hline DV & Scenario A & Scenario B & $\begin{array}{l}\text { Mean } \\
\text { difference } \\
\text { (A-B) }\end{array}$ & $\begin{array}{l}\text { Std. } \\
\text { error }\end{array}$ & Sig & \multicolumn{2}{l}{$\begin{array}{l}\text { 95\% } \\
\text { confidence interval }\end{array}$} \\
& & & & & $\begin{array}{l}\text { Lower } \\
\text { bound }\end{array}$ & $\begin{array}{l}\text { Upper } \\
\text { bound }\end{array}$ \\
\hline Usage & Sharing & Sharewashing & 0.5301 & 0.224 & 0.019 & 0.0898 & 0.9704 \\
& & Renting & 0.1011 & 0.223 & 0.650 & -0.3379 & 0.5402 \\
& \multirow{2}{*}{ Sharewashing } & Sharing & -0.5301 & 0.224 & 0.019 & -0.9704 & -0.0898 \\
& & Renting & -0.4290 & 0.214 & 0.047 & -0.8514 & -0.0065 \\
& \multirow{2}{*}{ Renting } & Sharing & -0.1011 & 0.223 & 0.650 & -0.5402 & 0.3379 \\
& & Sharewashing & 0.4290 & 0.214 & 0.047 & 0.0065 & 0.8514 \\
\hline
\end{tabular}

$\left(\mathrm{M}_{\text {sharewashing }}=4.05, \mathrm{M}_{\text {renting }}=4.48 ; \mathrm{F}(1,159)=3.97, p<0.05\right)$. Thus, we found initial evidence in support of our focal hypothesis, which we display in Fig. 2. These initial results were confirmed by post hoc tests (see Table 3 ). Beyond these postulated effects, we noted a surprising outcome: we did not find significant differences between the real sharing service and the traditional renting offer $(p=0.65)$, in that consumers demonstrated similar intentions to use these services.

\subsection{Study 2}

\subsubsection{Research Design and Sample}

In the second between-subjects experiment, we again used one independent variable on three levels. ${ }^{1}$ As in Study 1, we created appropriate stimulus material, namely press releases (see Appendix 2) that in this case considered a car-sharing context, which represents perhaps the most well-known form of access-based services, and thus a very common research context (Roos and Hahn 2017; Schaefers et al. 2016b). By using the car-sharing scenario and thus slightly changing the context, we could also test the initial findings' generalizability. We obtained the true sharing and renting communication stimulus from actual descriptions by car2go and Sixt, respectively. The company car2go is a car-sharing provider that the car manufacturer Daimler launched. It is located in various European cities as well as in North America (car2go 2019). The company car2go that merged with DriveNow (BMW's carsharing offer), is newly branded as SHARENOW (Mooney 2019). In contrast, Sixt is a traditional German car rental company present in several European countries and the United States. The company transformed its business model in 2019, offering various mobility services such as car rental and ride hailing on one platform (Sixt 2019). However, at the particular time when we conducted Study 2, the brand Sixt did not yet offer car-sharing services. For the sharewashing communication condition, we used their car rental description, but changed the heading and descriptions to

\footnotetext{
${ }^{1}$ Initially, we also varied the type of car (electric vs. conventional). However, we found no interaction effects along all variables $(\geq 0.322)$, therefore we investigated only the main effect of sharing, sharewashing, and renting while controlling for the possible confounding effects of the type of car (conventional car $=0$, $\mathrm{e}-\mathrm{car}=1)$.
} 
claim that it represented sharing. Every treatment was branded as a new offer by a car manufacturer (Audi), although such an offer did not actually exist.

We followed the same procedure as in Study 1 to obtain voluntary, anonymous participation for the survey and the attention check. Thus, manipulation checks asked whether the presented stimuli were communicating a sharing or a renting offer (e.g., "This offer relates to a sharing/renting service"). Participants who failed to pass these checks were screened out of the analysis. The final sample consisted of 287 participants, nearly equally distributed across the three scenarios of sharing $(N=95)$, sharewashing $(N=94)$, and traditional renting $(N=98)$. Respondents included a slight majority of women $(51 \%)$. The average age was 41 , with an age range between 16 and 87 .

\subsubsection{Measures}

The observed variables for this study are perceived attractiveness, information search, and usage intention (i.e., intention to use the service). All measures were based on seven-point Likert scales with multiple items to reduce measurement error. For perceived attractiveness of the new service, we adapted a scale from Boyd and Mason (1999) (e.g., "The presented offer can give me real value"). We operationalized information seeking according to van Ittersum and Feinberg (2010) and developed a four-item scale (e.g., "I would directly search for more information about the presented offer"). To measure usage intention, we used the Grewal et al. (1998) scale (e.g., "I would use this offer"). We detail all the measures in Appendix 3.

The reliability assessment for all scales uses Cronbach's alpha, and all of them exceed the generally accepted threshold of 0.70 (Hair 2010): attractiveness $=0.851$, information seeking $=0.921$, and usage intention $=0.903$. We determined values for each of the constructs by calculating the mean of the items on that scale. We also included gender $(0=$ female, $1=$ male $)$, age (measured in years), type of car, and brand attitude $(\alpha=0.916)$ as control variables in our analyses to control for potentially confounding effects.

\subsubsection{Common Method Bias}

Due to the study's research design, common method bias could be a concern. We applied Lindell and Whitney's (2001) MV marker variable approach to evaluate the severity of this potential common method bias (see also Wang et al. 2017). Thus, we included a theoretically unrelated marker variable in our questionnaire, measuring participants' attitude toward helping others (seven-point Likert scale, Cronbach's $\alpha=0.902$ ) adapted from Webb et al. (2000, p. 303), and we applied it as a marker variable. According to Lindell and Whitney (2001) and following current business research (Mandler et al. 2017; Wang et al. 2017), we used the smallest correlation between the marker variable and other variables to adjust the correlations between the variables. As presented in Table 4, none of the significant correlations became non-significant after the adjustment. This affirms that common method bias is not a serious issue in this study. 
Table 4 Descriptive statistics and correlations of the constructs-Study 2

\begin{tabular}{llllllll}
\hline & Construct & 1 & & 2 & & 3 & \\
\hline 1 & Attractiveness & 1.000 & - & 0.480 & $* * *$ & 0.630 & $* * *$ \\
2 & Information Seeking & 0.543 & $* * *$ & 1.000 & - & 0.580 & $* * *$ \\
3 & Usage Intention & 0.676 & $* * *$ & 0.614 & $* * *$ & 1.000 & - \\
& Marker & 0.141 & $*$ & 0.128 & $*$ & 0.200 & $* *$ \\
& Mean & 2.980 & - & 3.170 & - & 3.940 & - \\
& Std. Deviation & 1.580 & - & 1.670 & - & 1.560 & - \\
\hline
\end{tabular}

$N=287$. Zero-order correlations are below the diagonal; adjusted correlations for potential common method bias are above the diagonal.

$* p \leq 0.05, * * p \leq 0.01, * * * p \leq 0.001$

\subsubsection{Results}

In $\mathrm{H} 1-\mathrm{H} 3$, we predicted direct effects of firms' communication to introduce a new service (sharing, sharewashing, and traditional renting) on usage intention, perceived attractiveness, and information seeking. In the related ANOVAs, the communication stimuli represented the independent variable, and the constructs were the dependent variables. A full-factorial, multivariate analysis of covariance (MANCOVA) showed a significant multivariate main effect of the communication stimuli $(\mathrm{F}(6,556)=3.38, p<0.01)$. Follow-up univariate ANCOVAs revealed more details: intention to use the service was the lowest in the case of sharewashing $\left(\mathrm{M}_{\text {sharing }}=4.29>\mathrm{M}_{\text {sharewashing }}=3.49<\mathrm{M}_{\text {renting }}=4.03 ; \mathrm{F}(2,280)=7.54, p=0.001\right)$. The results were similar for attractiveness $\left(\mathrm{M}_{\text {sharing }}=3.35>\mathrm{M}_{\text {sharewashing }}=2.54<\mathrm{M}_{\text {renting }}=3.07\right.$; $\mathrm{F}(2,280)=7.06, p=0.001)$ and information seeking $\left(\mathrm{M}_{\text {sharing }}=3.60>\mathrm{M}_{\text {sharewashing }}=\right.$ $\left.2.77<\mathrm{M}_{\text {renting }}=3.13 ; \mathrm{F}(2,280)=6.04, p<0.01\right)$. To investigate these effects in more detail using the significance levels of the individual message framings, we analyzed the effects between treatments with post hoc tests. These results revealed that the likelihood of consumers using sharewashing offers was lower than of consumers using the real sharing offer $\left(\mathrm{M}_{\text {sharing }}=4.29\right.$ vs. $\left.\mathrm{M}_{\text {sharewashing }}=3.49, p<0.001\right)$ or the honest renting offer $\left(\mathrm{M}_{\text {sharewashing }}=3.49\right.$ vs. $\left.\mathrm{M}_{\text {renting }}=4.03, p<0.05\right)$. Thus, Study 2 also confirmed $\mathrm{H} 1$.

The results pertaining to attractiveness showed that the sharewashing treatment was perceived as less attractive than real sharing offers, which supports $\mathrm{H} 2 \mathrm{a}\left(\mathrm{M}_{\text {sharing }}=3.35\right.$ vs. $\left.\mathrm{M}_{\text {sharewashing }}=2.54, p=0.001\right)$. Similarly, sharewashing was perceived as less attractive than traditional rental offers, which supports $\mathrm{H} 2 \mathrm{~b}$ $\left(\mathrm{M}_{\text {sharewashing }}=2.54\right.$ vs. $\left.\mathrm{M}_{\text {renting }}=3.07, p<0.05\right)$. For information seeking intention, we found similar patterns: participants were more likely to report an intention to seek information about the sharing offer than about the sharewashing offer $\left(\mathrm{M}_{\text {sharing }}=3.60\right.$ vs. $\left.M_{\text {sharewashing }}=2.77, p=0.001\right)$. However, the difference between sharewashing and traditional renting was not significant $\left(\mathrm{M}_{\text {sharewashing }}=2.77\right.$ vs. $\left.\mathrm{M}_{\text {renting }}=3.13, p=0.133\right)$, therefore we can only confirm H3a. For a closer look at the data, Table 5 contains the ANOVA results, and Table 6 provides our post hoc tests' findings. In Fig. 3, the effects of sharewashing are plotted graphically.

Besides the traditional (co)variance based analysis of the direct effects in our experimental study, we aimed to investigate indirect effects. To investigate the com- 
Table 5 Analysis of covariance results-Study 2

\begin{tabular}{|c|c|c|c|c|c|c|c|c|}
\hline \multirow[t]{2}{*}{ Construct } & \multirow[b]{2}{*}{ SS } & \multirow[b]{2}{*}{ Df } & \multirow[b]{2}{*}{$\begin{array}{l}\text { Mean } \\
\text { square }\end{array}$} & \multirow[b]{2}{*}{$\mathrm{F}$} & \multirow[b]{2}{*}{$p$} & \multicolumn{2}{|c|}{ Means and Significance } & \multirow[b]{2}{*}{ Renting } \\
\hline & & & & & & Sharing & Sharewashing & \\
\hline $\begin{array}{l}\text { Usage Inten- } \\
\text { tion }\end{array}$ & 32.549 & 2 & 16.275 & 7.537 & 0.001 & $4.29^{\mathrm{a}}$ & $3.49^{\mathrm{b}}$ & $4.03^{\mathrm{a}}$ \\
\hline Attractiveness & 32.505 & 2 & 16.252 & 7.056 & 0.001 & $3.35^{\mathrm{a}}$ & $2.54^{\mathrm{b}}$ & $3.07^{\mathrm{a}}$ \\
\hline $\begin{array}{l}\text { Information } \\
\text { Seeking }\end{array}$ & 31.348 & 2 & 15.674 & 6.041 & 0.003 & $3.60^{\mathrm{a}}$ & $2.77^{\mathrm{b}}$ & $3.13^{\mathrm{b}}$ \\
\hline
\end{tabular}

The means in each row with different letters $(a, b)$ are significantly different from each other $(\mathrm{p} \leq 0.05)$

Table 6 Post hoc test for dependent variables-Study 2

\begin{tabular}{|c|c|c|c|c|c|c|c|}
\hline \multirow[t]{2}{*}{ DV } & \multirow[t]{2}{*}{ Scenario A } & \multirow[t]{2}{*}{ Scenario B } & \multirow{2}{*}{$\begin{array}{l}\text { Mean } \\
\text { difference } \\
(\mathrm{A}-\mathrm{B})\end{array}$} & \multirow[t]{2}{*}{$\begin{array}{l}\text { Std. } \\
\text { error }\end{array}$} & \multirow[t]{2}{*}{ Sig } & \multicolumn{2}{|c|}{$\begin{array}{l}95 \% \\
\text { confidence interval }\end{array}$} \\
\hline & & & & & & $\begin{array}{l}\text { Lower } \\
\text { bound }\end{array}$ & $\begin{array}{l}\text { Upper } \\
\text { bound }\end{array}$ \\
\hline \multirow{6}{*}{$\begin{array}{l}\text { Usage } \\
\text { Intention }\end{array}$} & \multirow[t]{2}{*}{ Sharing } & Sharewashing & 0.797 & 0.223 & 0.000 & 0.358 & 1.236 \\
\hline & & Renting & 0.256 & 0.221 & 0.248 & -0.179 & 0.691 \\
\hline & \multirow[t]{2}{*}{ Sharewashing } & Sharing & -0.797 & 0.223 & 0.000 & -1.236 & -0.358 \\
\hline & & Renting & -0.541 & 0.222 & 0.015 & -0.977 & -0.105 \\
\hline & \multirow[t]{2}{*}{ Renting } & Sharing & -0.256 & 0.221 & 0.248 & -0.691 & 0.179 \\
\hline & & Sharewashing & 0.541 & 0.222 & 0.015 & 0.105 & 0.977 \\
\hline \multirow[t]{6}{*}{ Attractiveness } & \multirow[t]{2}{*}{ Sharing } & Sharewashing & 0.810 & 0.226 & 0.000 & 0.365 & 1.255 \\
\hline & & Renting & 0.286 & 0.224 & 0.202 & -0.154 & 0.727 \\
\hline & \multirow[t]{2}{*}{ Sharewashing } & Sharing & -0.810 & 0.226 & 0.000 & -1.255 & -0.365 \\
\hline & & Renting & -0.524 & 0.224 & 0.020 & -0.966 & -0.082 \\
\hline & \multirow[t]{2}{*}{ Renting } & Sharing & -0.286 & 0.224 & 0.202 & -0.727 & 0.154 \\
\hline & & Sharewashing & 0.524 & 0.224 & 0.020 & 0.082 & 0.966 \\
\hline \multirow{6}{*}{$\begin{array}{l}\text { Information } \\
\text { Seeking }\end{array}$} & \multirow[t]{2}{*}{ Sharing } & Sharewashing & 0.831 & 0.238 & 0.001 & 0.362 & 1.301 \\
\hline & & Renting & 0.475 & 0.236 & 0.045 & 0.011 & 0.940 \\
\hline & \multirow[t]{2}{*}{ Sharewashing } & Sharing & -0.831 & 0.238 & 0.001 & -1.301 & -0.362 \\
\hline & & Renting & -0.356 & 0.237 & 0.133 & -0.822 & 0.109 \\
\hline & \multirow[t]{2}{*}{ Renting } & Sharing & -0.475 & 0.236 & 0.045 & -0.940 & -0.011 \\
\hline & & Sharewashing & 0.356 & 0.237 & 0.133 & -0.109 & 0.822 \\
\hline
\end{tabular}

munication messages' mediating effects on subsequent usage intention through attractiveness and information seeking, we also analyzed the data using PROCESS model 4 (version 2.16; Hayes 2013). It relies on ordinary least squares regression and bootstrapping procedures to estimate the direct and indirect effects, as well as mediation, moderation, and conditional (i.e., moderated mediation) processes using dichotomous independent variables. PROCESS produces estimates and bias-corrected bootstrap confidence intervals for the indirect effects. ${ }^{2}$ We started by including sharing and sharewashing as a dichotomous variable in Model A, then compared traditional renting and sharewashing in Model B (see Fig. 4). We ran controls (age, gender, brand attitude, and type of car) as covariates in both models. Unstandardized

\footnotetext{
2 The bootstrapping uses 5000 draws.
} 
Fig. 3 Mean plot of investigated variables-Study 2

\section{a Independent variable}

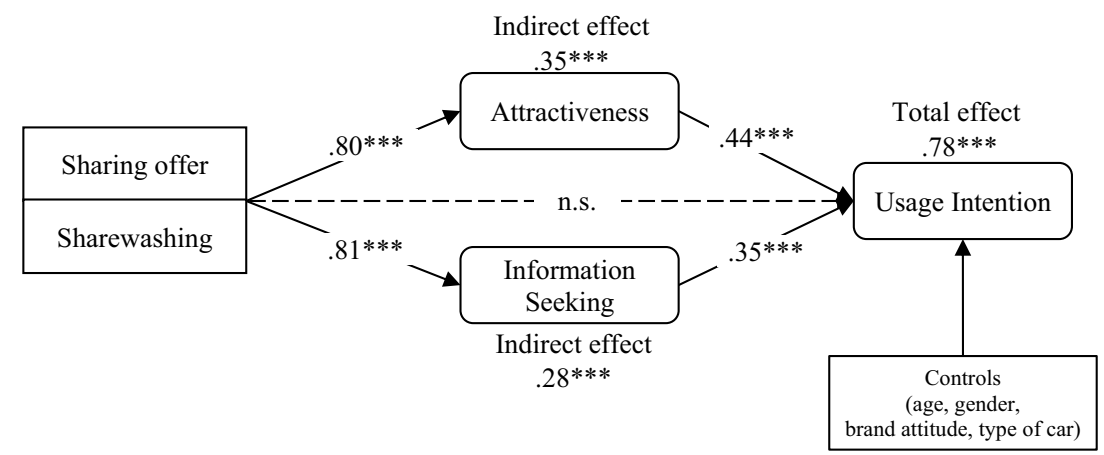

b Independent variable

Mediators

Dependent variable

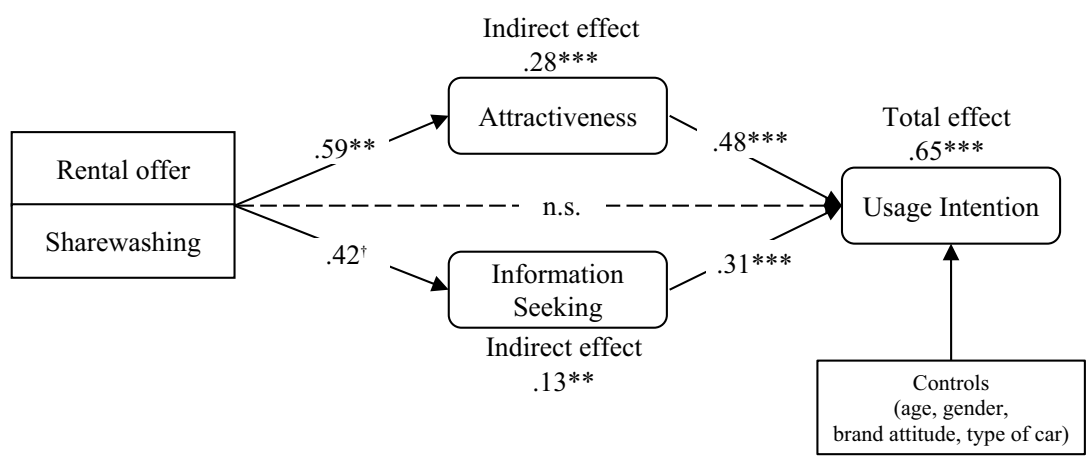

Fig. 4 Research models-Study 2; a Model A, b Model B, $\dagger<0.1 ; * p \leq 0.05 ; * * p \leq 0.01 ; * * * p \leq 0.001$; n.s. (not significant) $p \geq 0.1$ 
regression coefficients were reported for all analyses (Hayes 2013; Tian and Robertson 2019). The analysis results confirmed our direct effects findings. Specifically, the regressions on attractiveness revealed significant effects of sharing versus sharewashing $(b=0.80, t(183)=3.564, p<0.001)$ and renting versus sharewashing $(b=0.59$, $\mathrm{t}(186)=2.77, p<0.01)$. The regressions with information seeking showed a significant effect when we compared sharing to sharewashing $(b=0.81, t(183)=3.450$, $p<0.001$ ), but the renting versus sharewashing comparison indicated only a weakly significant difference $(b=0.42, \mathrm{t}(186)=1.81, p=0.072)$. The regressions for usage intention were not significant. However, this suggests full mediation. Attractiveness mediated the effect of sharing compared to sharewashing on usage intention $(\mathrm{B}=0.35$, standard error $[\mathrm{SE}]=0.11,99 \%$ bootstrap confidence interval $[\mathrm{CI}]=[0.11$, $0.66])$ and the effect of renting compared to sharewashing $(\mathrm{B}=0.28, \mathrm{SE}=0.11,99 \%$ $\mathrm{CI}=[0.03,0.59])$, supporting $\mathrm{H} 4 \mathrm{a}$ and $\mathrm{H} 4 \mathrm{~b}$. We also confirmed that information seeking has a mediating role. Thus, the results confirmed $\mathrm{H} 5 \mathrm{a}(\mathrm{B}=0.28, \mathrm{SE}=0.10$, $99 \% \mathrm{CI}=[0.08,0.58])$ as well as $\mathrm{H} 5 \mathrm{~b}(\mathrm{~B}=0.13, \mathrm{SE}=0.07,95 \% \mathrm{CI}=[0.001,0.30])$. The data further indicated significant total effects on the usage intention dependent variable for sharing versus sharewashing $(\mathrm{B}=0.78, \mathrm{SE}=0.21,99 \% \mathrm{CI}=[0.36,1.19])$ and for renting versus sharewashing $(\mathrm{B}=0.65, \mathrm{SE}=0.21,99 \% \mathrm{CI}=[0.23,1.07])$.

In addition to the hypothesized effects, we observed that participants' perceptions of real sharing and traditional renting offers do not differ; the two offers induced similar levels of approval. This means these types of services did not prompt significantly different usage intentions $\left(\mathrm{M}_{\text {sharing }}=4.29, \mathrm{M}_{\text {renting }}=4.03, p=0.25\right)$ or attractiveness ratings $\left(\mathrm{M}_{\text {sharing }}=3.35, \mathrm{M}_{\text {renting }}=3.07, p=0.20\right)$. The difference for informationseeking was slightly significant $\left(\mathrm{M}_{\text {sharing }}=3.60, \mathrm{M}_{\text {renting }}=3.13, p<0.05\right)$.

\subsection{Study 3}

To finally show the underlying mechanism that causes the less favorable results for misleading communication of offers, we replicated Study 2 with the addition of investigating the consumer skepticism's role.

\subsubsection{Research Design and Sample}

As in Study 2, we conducted a scenario-based, between-subjects experiment with the type of service being the independent variable distinguishing between three levels (sharing, renting, and sharewashing). We used the same stimuli as in Study 2, adjusting only the point of time when the new service would be launched. For data collection, the same methods were used as in Studies 1 and 2. To check for manipulation, we again asked participants how they would categorize the offer (as car-sharing, traditional car rental, or car-sharing offer based on a traditional car rental concept). For the data collection we used the survey tool Qualtrics. The final sample consisted of 199 participants with $N=83$ for the car-sharing, $N=54$ for the renting and $N=62$ for the sharewashing condition. Participants' mean age was 26.8 , with a minimum of 18 and a maximum of 69 years. Slightly more women $(54.3 \%)$ participated. 
Table 7 Reliability and validity assessment of constructs-Study 3

\begin{tabular}{llllllllll}
\hline & Construct & Alpha & CR & AVE & 1 & 2 & 3 & 4 & 5 \\
\hline 1 & Consumer & 0.913 & 0.917 & 0.788 & - & 0.427 & 0.368 & 0.470 & 0.255 \\
& Skepticism & & & & & & & & \\
2 & Attractiveness & 0.880 & 0.881 & 0.787 & $-0.399^{* *}$ & - & 0.754 & 0.728 & 0.200 \\
3 & Information & 0.882 & 0.886 & 0.666 & $-0.348^{* *}$ & $0.660^{* *}$ & - & 0.712 & 0.250 \\
& Seeking & & & & & & & & \\
4 & Usage Intention & 0.890 & 0.889 & 0.617 & $-0.465^{* *}$ & $0.643^{* *}$ & $0.628^{* *}$ & - & 0.205 \\
5 & Brand Attitude & 0.926 & 0.925 & 0.713 & $-0.196^{* *}$ & $0.179^{*}$ & $0.277^{* *}$ & $0.185^{* *}$ & - \\
\hline
\end{tabular}

$* p \leq 0.05, * * p \leq 0.01$; correlations are reported below the diagonal, heterotrait-monotrait ratio of correlations (HTMT values) are reported above the diagonal

\subsubsection{Measures}

We used the same scales as in Study 2. To measure consumer skepticism, we adapted Babin et al.'s (1995) scale using a seven-point Likert scale with three items ("Concerning the offer, I am skeptical/suspicious/critical"). We assessed the scales' reliability and validity and found that all the criteria fulfilled the common thresholds so that they could be used in further calculations (Hair et al. 2017; see Table 7). As in Study 2, we controlled for brand attitude, age (measured in years), and gender $(0=$ male, $1=$ female $)$.

\subsubsection{Results}

To test for the effect the communicated type of service has on consumer skepticism (H6) and usage intention (H1) we conducted a multivariate analysis of covariance (MANCOVA) with age, gender, and brand attitude as covariates. The MANCOVA showed a significant multivariate main effect of the three manipulations $(\mathrm{F}(4,386)=8.22, p<0.001)$. The follow-up univariate ANCOVAs revealed that consumer skepticism was the highest for the sharewashing offer $\left(\mathrm{M}_{\text {sharewashing }}=4.65>\mathrm{M}_{\text {renting }}=4.56>\mathrm{M}_{\text {sharing }}=3.57 ; \mathrm{F}(2,193)=10.24, p<0.001\right)$, and usage intention was the lowest in the case of sharewashing $\left(\mathrm{M}_{\text {sharewashing }}=3.36<\right.$ $\left.\mathrm{M}_{\text {renting }}=3.92<\mathrm{M}_{\text {sharing }}=4.36 ; \mathrm{F}(2,193)=12.19, p<0.001\right)$.

With follow-up post hoc tests we analyzed the effects between the different treatment groups and account for the different sample sizes. As hypothesized in H6a, results revealed higher consumer skepticism for the sharewashing offer than for the sharing offer $\left(\mathrm{M}_{\text {sharewashing }}=4.65\right.$ vs. $\left.\mathrm{M}_{\text {sharing }}=3.57, p<0.001\right)$. Surprisingly, the rental offer caused similarly high consumer skepticism $\left(\mathrm{M}_{\text {sharewashing }}=4.65 \mathrm{vs}\right.$. $\mathrm{M}_{\text {renting }}=4.56, p=0.985$ ), thus, showing no support for H6b. Although we did not hypothesize any difference related to consumer skepticism between the sharing and rental offers, it is interesting that consumer skepticism was significantly higher for the rental offer than for the sharing offer $\left(\mathrm{M}_{\text {sharing }}=3.57\right.$ vs. $\left.\mathrm{M}_{\text {renting }}=4.56, p<0.01\right)$. Our discussion below will elaborate on this finding in more detail.

The results for usage intention show that the sharewashing offer leads to lower usage intention than the real sharing offer $\left(M_{\text {sharewashing }}=3.36\right.$ vs. $M_{\text {sharing }}=4.36$, $p<0.001$ ), which supports H1a. Although consumers tend to use the rental offer 
Table 8 Analysis of covariance results-Study 3

\begin{tabular}{lllllllll}
\hline Construct & & & & & & \multicolumn{3}{c}{ Means and Significance } \\
& SS & Df & $\begin{array}{l}\text { Mean } \\
\text { square }\end{array}$ & F & $p$ & Sharing & $\begin{array}{l}\text { Share- } \\
\text { washing }\end{array}$ & Renting \\
\hline Usage Intention & 40,074 & 2 & 20,037 & 12,188 & 0.000 & $4.36^{\mathrm{a}}$ & $3.36^{\mathrm{b}}$ & $3.92^{\mathrm{a}, \mathrm{b}}$ \\
Consumer Skepticism & 54,209 & 2 & 27,105 & 10,235 & 0.000 & $3.57^{\mathrm{a}}$ & $4.65^{\mathrm{b}}$ & $4.56^{\mathrm{b}}$ \\
\hline
\end{tabular}

The means in each row with different letters $(a, b)$ are significantly different from each other $(\mathrm{p} \leq 0.05)$

Table 9 Post hoc test for consumer skepticism and usage intention-Study 3

\begin{tabular}{|c|c|c|c|c|c|c|c|}
\hline \multirow[t]{2}{*}{$\overline{\mathrm{DV}}$} & \multirow[t]{2}{*}{ Scenario A } & \multirow[t]{2}{*}{ Scenario B } & \multirow{2}{*}{$\begin{array}{l}\text { Mean } \\
\text { difference } \\
(\mathrm{A}-\mathrm{B})\end{array}$} & \multirow[t]{2}{*}{$\begin{array}{l}\text { Std. } \\
\text { error }\end{array}$} & \multirow[t]{2}{*}{ Sig } & \multicolumn{2}{|c|}{$\begin{array}{l}95 \% \\
\text { confidence interval }\end{array}$} \\
\hline & & & & & & $\begin{array}{l}\text { Lower } \\
\text { bound }\end{array}$ & $\begin{array}{l}\text { Upper } \\
\text { bound }\end{array}$ \\
\hline \multirow{6}{*}{$\begin{array}{l}\text { Usage } \\
\text { Intention }\end{array}$} & \multirow[t]{2}{*}{ Sharing } & Sharewashing & 1.006 & 0.225 & 0.000 & 0.465 & 1.547 \\
\hline & & Renting & 0.445 & 0.234 & 0.165 & -0.118 & 1.001 \\
\hline & \multirow[t]{2}{*}{ Sharewashing } & Sharing & -1.006 & 0.225 & 0.000 & -1.547 & -0.465 \\
\hline & & Renting & -0.561 & 0.249 & 0.075 & -1.160 & 0.040 \\
\hline & \multirow[t]{2}{*}{ Renting } & Sharing & -0.445 & 0.234 & 0.165 & -1.001 & 0.118 \\
\hline & & Sharewashing & 0.561 & 0.249 & 0.075 & -0.040 & 1.161 \\
\hline \multirow{6}{*}{$\begin{array}{l}\text { Consumer } \\
\text { Skepti- } \\
\text { cism }\end{array}$} & \multirow[t]{2}{*}{ Sharing } & Sharewashing & -1.087 & 0.279 & 0.000 & -1.759 & -0.415 \\
\hline & & Renting & -0.989 & 0.291 & 0.002 & -1.689 & -0.290 \\
\hline & \multirow[t]{2}{*}{ Sharewashing } & Sharing & 1.087 & 0.279 & 0.000 & 0.415 & 1.759 \\
\hline & & Renting & 0.098 & 0.309 & 0.985 & -0.647 & 0.843 \\
\hline & \multirow[t]{2}{*}{ Renting } & Sharing & 0.989 & 0.291 & 0.002 & 0.290 & 1.689 \\
\hline & & Sharewashing & -0.098 & 0.309 & 0.985 & -0.843 & 0.647 \\
\hline
\end{tabular}

rather than the sharewashing offer $\left(\mathrm{M}_{\text {sharewashing }}=3.36\right.$ vs. $\left.\mathrm{M}_{\text {renting }}=3.92, p=0.075\right)$, results show support for $\mathrm{H} 1 \mathrm{~b}$ on a level of merely $p=0.1$. Additionally, the results revealed that although the rental offer causes more skepticism than the sharing offer, there was no significant difference in usage intention for renting compared to sharing $\left(\mathrm{M}_{\text {sharing }}=4.36\right.$ vs. $\left.\mathrm{M}_{\text {renting }}=3.92, p=0.165\right)$. While Table 8 shows the ANCOVA results, Table 9 displays the post hoc tests' results. Then in Fig. 5, we plot the effects graphically.

We examined the mediating effect of consumer skepticism (H7) based on a simple mediation model using partial least squares structural equation modeling (PLS_SEM) (Sarstedt et al. 2020). To compare the different communication stimuli, i.e., the different types of offers, we defined sharewashing as the comparison group (0) for the dummy regressions. Hence, the effects of the sharing offer and the renting offer need to be interpreted in relation to the sharewashing offer (cf. Eggert et al. 2015). We calculated all data with SmartPLS 3.0 software (Ringle et al. 2015). Hence, we ran the PLS algorithm, followed by the bootstrapping procedure using 5000 samples.

The results of the simple mediation model are depicted in Table 10. As already shown in the previous analysis, a sharing offer compared to a sharewashing offer not only showed a significant effect on consumer skepticism $(\beta=-0.321, p<0.001)$ and on usage intention $(\beta=0.285, p<0.001)$, but also revealed a significant indirect 
Fig. 5 Mean plot of investigated variables-Study 3

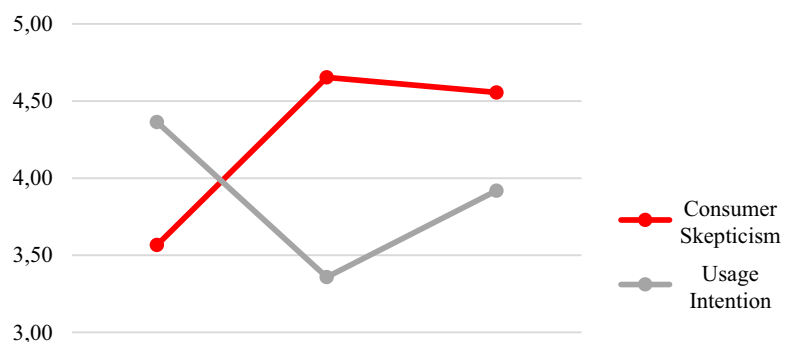

2,50

2,00

effect via consumer skepticism on usage intention $(\beta=0.123, p<0.01)$, thus supporting H1a, H6a and H7a. Hence, consumer skepticism partially mediates the impact of a sharing offer (versus sharewashing) on usage intention. The results for a traditional car rental offer compared to a sharewashing offer showed a significant effect only on usage intention $(\beta=0.216, p<0.01)$, thus supporting H1b. Surprisingly, the direct effect of a traditional car rental offer (versus sharewashing) on consumer skepticism was not significant $(\beta=-0.046, p=0.567)$, as was the indirect effect $(\beta=0.017$, $p=0.576$ ), hence $\mathrm{H} 6 \mathrm{~b}$ and $\mathrm{H} 7 \mathrm{~b}$ were not supported.

To not only test the simple mechanism of consumer skepticism on usage intention we also included perceived attractiveness of the offer and information seeking as second level mediators. Additionally, we ran the PLS algorithm for the complete model. We found significant direct effects of a car-sharing offer compared to a sharewashing offer on consumer skepticism $(\beta=-0.320, p<0.001)$, perceived offer attractiveness $(\beta=0.250, p<0.01)$, and information seeking behavior $(\beta=0.212$, $p<0.05)$, which support hypotheses $\mathrm{H} 2 \mathrm{a}, \mathrm{H} 3 \mathrm{a}$, and H6a. The direct effect on usage intention $(\beta=0.113, p=0.069)$ was significant on a ten percent probability level only, thus showing weak support for H1a. Beyond these direct effects, the specific indirect effect via consumer skepticism on usage intention $(\beta=0.053, p<0.05)$ was significant, thus supporting H7a. Additionally, the specific indirect effect via attractiveness of the offer $(\beta=0.107, p<0.05)$ was significant. However, the indirect effect via information seeking $(\beta=0.061, p=0.123$ ) was not significant. Concerning the serial mediation, results revealed a significant indirect effect via consumer skepticism and attractiveness $(\beta=0.042, p<0.05)$ of car-sharing (versus sharewashing) on usage intention, whereas the indirect effect via consumer skepticism and information seeking intention $(\beta=0.025, p=0.113)$ was not significant. The specific indirect and total indirect effects as well as the total effects are depicted in Table 11.

While we also suggested a positive effect of a car rental offer compared to a sharewashing offer, the results did not show significant direct effects on consumer skepticism $(\beta=-0.046, p=0.565)$, attractiveness of the offer $(\beta=-0.058, p=0.397)$, and information seeking $(\beta=0.110, p=0.175)$, thus providing no support for $\mathrm{H} 2 \mathrm{~b}, \mathrm{H} 3 \mathrm{~b}$, and H6b. Hence, the specific indirect effects via consumer skepticism, attractiveness of the offer, and information seeking were not significant. However, the direct 
Table 10 Results of the simple mediation model—Study 3

\begin{tabular}{|c|c|c|c|}
\hline Direct Effects & $\beta$ & $t$ values & $p$ values \\
\hline Sharing $^{a} \rightarrow$ Consumer Skepticism & -0.321 & 4.153 & 0.000 \\
\hline Sharing $^{a} \rightarrow$ Usage Intention & 0.285 & 3.654 & 0.000 \\
\hline Renting $^{a} \rightarrow$ Consumer Skepticism & -0.046 & 0.573 & 0.567 \\
\hline Renting $^{a} \rightarrow$ Usage Intention & 0.216 & 2.837 & 0.005 \\
\hline Consumer Skepticism $\rightarrow$ Usage Intention & -0.382 & 5.074 & 0.000 \\
\hline \multicolumn{4}{|l|}{ Specific Indirect Effects } \\
\hline Sharing $^{a} \rightarrow$ Consumer Skepticism $\rightarrow$ Usage Intention & 0.123 & 3.027 & 0.002 \\
\hline Renting $^{a} \rightarrow$ Consumer Skepticism $\rightarrow$ Usage Intention & 0.017 & 0.559 & 0.576 \\
\hline \multicolumn{4}{|l|}{ Total Effects } \\
\hline Sharing $^{a} \rightarrow$ Usage Intention & 0.408 & 5.413 & 0.000 \\
\hline Renting $^{a} \rightarrow$ Usage Intention & 0.233 & 2.839 & 0.005 \\
\hline \multicolumn{4}{|l|}{ Covariates (Direct Effects) } \\
\hline Gender $^{b} \rightarrow$ Consumer Skepticism & -0.011 & 0.162 & 0.871 \\
\hline Gender $^{b} \rightarrow$ Usage Intention & 0.065 & 0.958 & 0.338 \\
\hline Brand Attitude $\rightarrow$ Consumer Skepticism & -0.251 & 3.350 & 0.001 \\
\hline Brand Attitude $\rightarrow$ Usage Intention & 0.111 & 1.470 & 0.142 \\
\hline Age $\rightarrow$ Consumer Skepticism & 0.071 & 1.044 & 0.296 \\
\hline Age $\rightarrow$ Usage Intention & -0.178 & 2.535 & 0.011 \\
\hline- & \multicolumn{3}{|c|}{$R$ square adjusted } \\
\hline Consumer Skepticism & \multicolumn{3}{|l|}{0.135} \\
\hline Usage Intention & \multicolumn{3}{|l|}{0.313} \\
\hline
\end{tabular}

$\beta=$ standardized path coefficient

${ }^{a}$ compared to sharewashing (0)

${ }^{b}$ gender: male $=0$, female $=1$

effect of a car rental offer (versus sharewashing) on usage intention was significant ( $\beta=0.209, p<0.01$ ), which supports H1b. We give a comprehensive overview of the main results in Table 11 .

\section{General Discussion}

This research has investigated sharewashing, which is a concept we introduce to describe the behavior of various firms laying claim to a position in the sharing economy without developing an innovative service; rather, they misleadingly frame a traditional service as sharing. Drawing on attribution theory and consumer skepticism research, we predict negative consequences of such behavior, and provide empirical evidence of consumers' diminished intentions to use such a deceptively communicated service.

\subsection{Theoretical Contributions}

Our findings across three studies contribute to research and theory in several ways. First, we contribute to the research streams of access-based services and deceptive 
Table 11 Results of the complete model evaluation-Study 3

\begin{tabular}{|c|c|c|c|}
\hline Direct Effects & $\beta$ & $\mathrm{t}$ values & $p$ values \\
\hline Sharing $^{a} \rightarrow$ Consumer Skepticism & -0.320 & 4.206 & 0.000 \\
\hline Sharing $^{a} \rightarrow$ Attractiveness & 0.250 & 2.944 & 0.003 \\
\hline Sharing $^{a} \rightarrow$ Information Seeking & 0.212 & 2.53 & 0.011 \\
\hline Sharing $^{a} \rightarrow$ Usage Intention & 0.113 & 1.821 & 0.069 \\
\hline Renting $^{a} \rightarrow$ Consumer Skepticism & -0.046 & 0.576 & 0.565 \\
\hline Renting $^{a} \rightarrow$ Attractiveness & -0.058 & 0.847 & 0.397 \\
\hline Renting $^{a} \rightarrow$ Information Seeking & 0.110 & 1.357 & 0.175 \\
\hline Renting $^{a} \rightarrow$ Usage Intention & 0.209 & 3.026 & 0.002 \\
\hline Consumer Skepticism $\rightarrow$ Attractiveness & -0.303 & 3.488 & 0.000 \\
\hline Consumer Skepticism $\rightarrow$ Information Seeking & -0.269 & 3.239 & 0.001 \\
\hline Consumer Skepticism $\rightarrow$ Usage Intention & -0.166 & 2.677 & 0.007 \\
\hline Attractiveness $\rightarrow$ Usage Intention & 0.429 & 3.021 & 0.003 \\
\hline Information Seeking $\rightarrow$ Usage Intention & 0.289 & 2.283 & 0.022 \\
\hline \multicolumn{4}{|l|}{ Specific Indirect Effects } \\
\hline Sharing $^{a} \rightarrow$ Consumer Skepticism $\rightarrow$ Usage Intention & 0.053 & 2.179 & 0.029 \\
\hline Renting $^{a} \rightarrow$ Consumer Skepticism $\rightarrow$ Usage Intention & 0.008 & 0.513 & 0.608 \\
\hline \multicolumn{4}{|c|}{ Specific Indirect Effects via Consumer Skepticism and Attractiveness } \\
\hline Sharing ${ }^{a} \rightarrow$ Consumer Skepticism $\rightarrow$ Attractiveness & 0.097 & 2.457 & 0.014 \\
\hline $\begin{array}{l}\text { Sharing }{ }^{a} \rightarrow \text { Consumer Skepticism } \rightarrow \text { Attractiveness } \rightarrow \\
\text { Usage Intention }\end{array}$ & 0.042 & 1.990 & 0.047 \\
\hline Sharing $^{a} \rightarrow$ Attractiveness $\rightarrow$ Usage Intention & 0.107 & 2.135 & 0.033 \\
\hline Renting $^{a} \rightarrow$ Consumer Skepticism $\rightarrow$ Attractiveness & 0.014 & 0.553 & 0.580 \\
\hline $\begin{array}{l}\text { Renting }^{a} \rightarrow \text { Consumer Skepticism } \rightarrow \text { Attractiveness } \rightarrow \\
\text { Usage Intention }\end{array}$ & 0.006 & 0.543 & 0.587 \\
\hline Renting $^{a} \rightarrow$ Attractiveness $\rightarrow$ Usage Intention & -0.025 & 0.786 & 0.432 \\
\hline \multicolumn{4}{|c|}{ Specific Indirect Effects via Consumer Skepticism and Information Seeking } \\
\hline $\begin{array}{l}\text { Sharing }{ }^{a} \rightarrow \text { Consumer Skepticism } \rightarrow \text { Information } \\
\text { Seeking }\end{array}$ & 0.086 & 2.329 & 0.020 \\
\hline $\begin{array}{l}\text { Sharing }{ }^{a} \rightarrow \text { Consumer Skepticism } \rightarrow \text { Information } \\
\text { Seeking } \rightarrow \text { Usage Intention }\end{array}$ & 0.025 & 1.585 & 0.113 \\
\hline Sharing $^{a} \rightarrow$ Information Seeking $\rightarrow$ Usage Intention & 0.061 & 1.544 & 0.123 \\
\hline $\begin{array}{l}\text { Renting }^{a} \rightarrow \text { Consumer Skepticism } \rightarrow \text { Information } \\
\text { Seeking }\end{array}$ & 0.012 & 0.539 & 0.590 \\
\hline $\begin{array}{l}\text { Renting }^{a} \rightarrow \text { Consumer Skepticism } \rightarrow \text { Information } \\
\text { Seeking } \rightarrow \text { Usage Intention }\end{array}$ & 0.004 & 0.488 & 0.625 \\
\hline Renting $^{a} \rightarrow$ Information Seeking $\rightarrow$ Usage Intention & 0.032 & 1.057 & 0.290 \\
\hline \multicolumn{4}{|l|}{ Total Indirect Effects } \\
\hline Sharing $^{a} \rightarrow$ Attractiveness & 0.097 & 2.457 & 0.014 \\
\hline Sharing $^{a} \rightarrow$ Information Seeking & 0.086 & 2.329 & 0.020 \\
\hline Sharing ${ }^{a} \rightarrow$ Usage Intention & 0.288 & 4.926 & 0.000 \\
\hline Renting $^{a} \rightarrow$ Attractiveness & 0.014 & 0.553 & 0.580 \\
\hline Renting $^{a} \rightarrow$ Information Seeking & 0.012 & 0.539 & 0.590 \\
\hline Renting $^{a} \rightarrow$ Usage Intention & 0.024 & 0.395 & 0.693 \\
\hline Consumer Skepticism $\rightarrow$ Usage Intention & -0.208 & 3.461 & 0.001 \\
\hline Total Effects & & & \\
\hline
\end{tabular}


Table 11 (Continued)

\begin{tabular}{|c|c|c|c|}
\hline Sharing $^{a} \rightarrow$ Attractiveness & 0.347 & 4.436 & 0.000 \\
\hline Sharing $^{a} \rightarrow$ Information Seeking & 0.298 & 3.885 & 0.000 \\
\hline Sharing $^{a} \rightarrow$ Usage Intention & 0.401 & 5.438 & 0.000 \\
\hline Renting $^{a} \rightarrow$ Attractiveness & -0.044 & 0.605 & 0.545 \\
\hline Renting $^{a} \rightarrow$ Information Seeking & 0.123 & 1.489 & 0.136 \\
\hline Renting $^{a} \rightarrow$ Usage Intention & 0.233 & 2.858 & 0.004 \\
\hline Consumer Skepticism $\rightarrow$ Usage Intention & -0.373 & 4.810 & 0.000 \\
\hline \multicolumn{4}{|l|}{ Covariates (Direct Effects) } \\
\hline Gender $^{b} \rightarrow$ Consumer Skepticism & -0.012 & 0.168 & 0.866 \\
\hline Gender $^{b} \rightarrow$ Attractiveness & -0.019 & 0.267 & 0.790 \\
\hline Gender $^{b} \rightarrow$ Information Seeking & 0.095 & 1.332 & 0.183 \\
\hline Gender $^{b} \rightarrow$ Usage Intention & 0.044 & 0.763 & 0.446 \\
\hline Brand Attitude $\rightarrow$ Consumer Skepticism & -0.252 & 3.355 & 0.001 \\
\hline Brand Attitude $\rightarrow$ Attractiveness & 0.122 & 1.833 & 0.067 \\
\hline Brand Attitude $\rightarrow$ Information Seeking & 0.171 & 2.353 & 0.019 \\
\hline Brand Attitude $\rightarrow$ Usage Intention & 0.012 & 0.205 & 0.837 \\
\hline Age $\rightarrow$ Consumer Skepticism & 0.072 & 1.056 & 0.291 \\
\hline Age $\rightarrow$ Attractiveness & -0.128 & 1.695 & 0.090 \\
\hline Age $\rightarrow$ Information Seeking & -0.091 & 1.074 & 0.283 \\
\hline Age $\rightarrow$ Usage Intention & -0.095 & 1.895 & 0.058 \\
\hline- & \multicolumn{3}{|c|}{$R$ square adjusted } \\
\hline Consumer Skepticism & \multicolumn{3}{|c|}{0.135} \\
\hline Attractiveness & \multicolumn{3}{|l|}{0.261} \\
\hline Information Seeking & \multicolumn{3}{|l|}{0.183} \\
\hline Usage Intention & \multicolumn{3}{|l|}{0.641} \\
\hline
\end{tabular}

$\beta=$ standardized path coefficient

${ }^{a}$ compared to sharewashing (0)

${ }^{b}$ gender: male $=0$, female $=1$

communication by introducing and empirically testing the recent phenomenon that companies try to exploit the emerging trend of the sharing economy and collaborative consumption by making deceptive offers, i.e., sharewashing. While extant research on access-based services predominantly focuses on positive aspects of the sharing economy we document a negative outcome of this emerging consumption trend. Hereby, we go further than studies praising access-based services as a new business paradigm (Belk 2014b; Botsman and Rogers 2010) often used to enhance a company's image (Baumeister et al. 2015). By identifying and classifying misleading communication of alleged sharing offers as deceptive communication and revealing its negative consequences in three related studies, we provide initial empirical evidence of a sharewashing effect. The latter is similar to the greenwashing effect established largely in CSR research (Leonidou and Skarmeas 2017; Nyilasy et al. 2014; Skarmeas and Leonidou 2013). We thereby broaden the research field beyond sustainability ("green") and CSR communication (e.g., Romani et al. 2016) and provide evidence for the generalizability of this deceptive communication concept. We show its negative consequences for companies that try to exploit a new 
market by misleadingly labeling their business model as sharing without delivering a real sharing service.

Second, regarding the literature streams of consumer skepticism and deceptive communication, we contribute to extant research by identifying partially different and inconsistent mechanisms that affect consumer attitudes and behaviors in a sharing context. Previous research on green advertising and CSR shows higher levels of skepticism toward dishonest communication or activities, which have a negative effect on consumers' behavioral intentions (Skarmeas and Leonidou 2013; Nyilasy et al. 2014). However, results are not as clear regarding deceptive communication of companies entering the market of access-based mobility services. In line with previous research, we confirm the expected mediating mechanism of consumer skepticism between the communicated type of service and usage intention, showing that sharewashing causes more consumer skepticism and thus lower usage intention than a real car-sharing offer. Surprisingly, this mechanism does not hold true in comparing a traditional car rental offer and a sharewashing offer. Although both offers caused similarly high levels of consumer skepticism, usage intentions were higher for a traditional rental offer than for a sharewashing offer. To better understand these results, we need to consider the rapidly changing mobility services market. While the global car rental market is confronted with decreasing growth rates (Statista 2019), car-sharing has been disproportionately expanding with new players entering the market. In fact, the car-sharing market grew from 3 million car-sharing platform members worldwide in 2013 to 27 million in 2018 (Kearney 2019). Thus, consumers have gained more experience and knowledge about actors and state-ofthe-art offers in this disrupted market. Hence, we assume that consumers do not credit companies that enter the mobility market with a traditional service concept such as car rental; quite the contrary, consumers seem to be similarly skeptical toward these types of offers, particularly when they are newly introduced to the market. Consequently, we believe that the reasons for consumer skepticism toward the sharewashing and renting offers, are different. Whereas we presume consumer skepticism in the sharewashing condition is caused by consumers' feeling of being deceived or dishonestly treated by the service provider, their skepticism toward the rental service rather displays a state of irritation and confusion. Nevertheless, consumers' usage intentions are higher for rental offers than for sharewashing offers. These results indicate that a different, simultaneous mechanism exists in the case of rental offers and mitigates the negative effect of consumer skepticism on usage intention. This parallel mechanism seems to be based on the mere-exposure effect (Zajonc 1968) because in the past consumers have had regular exposure to such traditional rental offers, and therefore might be more familiar with a rental offer than a newly introduced sharewashing offer with renting characteristics, but framed as sharing. Accordingly, a familiar rental offer might increase positive affect, and thus cause a direct positive effect on usage intentions. These findings are consistent with Ward et al.'s (2014) research that, in another context, confirmed the power of familiarity to predict consumer choice. However, to fully understand the specific interplay between the competing mechanisms of skepticism and familiarity further research is required. 
Third, we apply attribution theory to explain the new phenomenon of sharewashing and its negative effects. Based on attribution theory, we demonstrate an inner process, captured by mediating variables that indicate passive and active interest. More precisely, we reveal a downstream process in which consumers, on careful consideration, might begin to form negative attributions about the company's motives. We presume they suspect companies of having ulterior motives, which leads them to turn away from such companies and their offers. Thereby, our findings agree with previous research on greenwashing (Nyilasy et al. 2014), showing similar effects on how skepticism that results from consumers' attributions triggered by deceptive communications, leads to predominantly negative psychological and behavioral responses.

\subsection{Managerial Implications}

Our research findings hold important implications for businesses, of which managers should be aware. Evidence of the negative consequences of sharewashing emphasizes how important honest communication is.

Our findings show that companies should be aware of sharewashing's negative effects and need to distinguish themselves from competitors that try to jump on the bandwagon. Besides the possibility that the emerging market of sharing services could suffer in the long run, such sharewashing practices could backfire on a single service provider as well. Hence, we suggest that firms should either pursue a real sharing option or embrace a traditional renting approach and promote it accordingly. Whereas sharewashing prompts negative perceptions and intentions, sharing as well as renting offers do not evoke significantly different usage intentions among consumers. Therefore, even if a company is unable to adopt the new consumption trend of sharing, it should still prioritize communicating what it offers instead of misleadingly framing the offer as sharing. This highlights the need for a clear business concept and honest communication.

Further, our investigation of the mediating effects in Study 2 suggests that consumers need to understand the value proposition of a service. Companies entering a highly dynamic market with a deceptively communicated service will trigger neither active nor passive consumer interest. For this reason, it is particularly important to know and communicate the consumers' perceived value of the offered service in order to spark active interest and trigger additional information seeking, both of which are highly relevant for subsequent usage or buying intentions.

However, companies entering the market with a traditional renting service could encounter more challenges to trigger active and passive interest. Although consumers' usage intentions between a traditional renting and a real car-sharing offer did not differ significantly, Study 3 revealed that consumers are more skeptical of a market entry with a traditional rental business model than of one with a sharing model. Hence, entering a highly disrupted market, such as the mobility sector, with a traditional rental service can cause skepticism among consumers. Although consumers are familiar with traditional rental services and still intend to use such a service, they might question why a company does not offer a modern car-sharing service when newly entering the market, since even traditional rental car companies 
such as Sixt are transforming their business model by establishing a "mobility as a service" platform and offering rental, sharing, and ride hailing services in one mobile application (FleetEurope 2019; Market Insider 2019). This case demonstrates that even traditional rental companies can rethink their business model and innovate, offering both rental and sharing services to increase car utilization, thus staying competitive as the market in which they are operating is changing radically. However, (additionally) offering true car-sharing can be costly. Recent developments indicate that flexible product usage through access-based services is not suitable in all business environments and could in practice be too expensive in some contexts (Dahlmann 2016; Hahn et al. 2020; Lagadic et al. 2019; Löhle 2017). For this reason, some firms may still find traditional renting services an appealing and profitable option. Still, companies that pursue a market entry with a traditional rental service might need to invest more effort and financial resources in marketing communication to spark consumers' passive and active interest. In the long run this is particularly relevant for companies to differentiate themselves from other entrants or existing competitors.

\subsection{Limitations and Further Research}

Our results should also be interpreted in the light of certain limitations. First, to achieve a high degree of internal validity, we used experiments which could be limited in their external validity. We developed realistic experimental stimulus materials (i.e., based on real-world communications), but external validity remains a concern. Therefore, further research could gather field data or conduct field experiments to ensure cross-validation.

Second, although we found evidence for a negative sharewashing effect on usage intentions in different mobility contexts (i.e., scooters and cars) and for different brands (i.e., Deutsche Bahn and Audi), future research could investigate whether sharewashing has the same negative effects for a strong versus a weak brand, or a well-known versus a new, lesser known brand.

Finally, our work represents one of the first steps taking a more critical perspective on the trend of access-based services and collaborative consumption. Research on the dark side of the sharing economy remains scarce in these domains, so we outline several potential avenues for further studies. In particular, we call for projects that investigate social impact. On a macro level, novel sharing services can produce concentrations of ownership, in that a majority of potential consumers would eventually only be able to access these products by paying higher prices. In various industries, companies have entered into vicious competition with new providers in the sharing economy. Uber drivers, for instance, challenge taxi drivers in many cities, and Airbnb makes business in the hospitality industry more competitive. Authorities have already responded, for example by banning Uber in London (Wilkinson 2018). This development follows the trend to the hub or platform economy (Perren and Kozinets 2018), which intensifies concentration of supply. Further studies should investigate possible dark sides, such as negative effects on consumers, on competitive structures in industries, and on society as a whole. On a micro level, we need research on the negative consequences of access-based consumption for both customers and for 
peer service providers. For example, consumers could face inconvenience and higher quality risks when they adopt unstandardized collaborative services. Emerging risks also relate to data protection and privacy, due to the expanded means of tracking consumers' access to and use of various services. Service providers harvest vast amounts of user data, which certainly create risks of data misuse or loss, as well as evoke consumers' skepticism about how companies handle their personal data. This topic is of great public interest, and not only since Facebook's data privacy scandal (BBC News 2018). The use of blockchain technology for managing access-based services and peer-to-peer networks might be a promising approach to handle data protection and privacy concerns (Büttgen et al. 2021). Summarizing, future research should focus on these dark side aspects and keep a critical eye on this consumption trend. 


\section{Appendix}

\section{Appendix 1: Study 1-Experimental Stimuli}

\section{E-Scooter-Sharing from DB} Deutsche Bahn starts a sharing offer for electro-

\section{Die Bahn DB} scooters

In future, the sharing offer will be available in many German cities. Available scooters can be searched and reserved in the browser or via the app in advance. After the ride, the e-scooters can easily be parked in the operation area or, for a credit advice for the next trip, by a charging station. The offer is available to everyone after a one-time registration. Because the scooters are regularly maintained, they are always in a good condition and fully functional. Billing is based on the duration of usage, with a flexible tariff. Detailed information about the offer is summarized in the table.

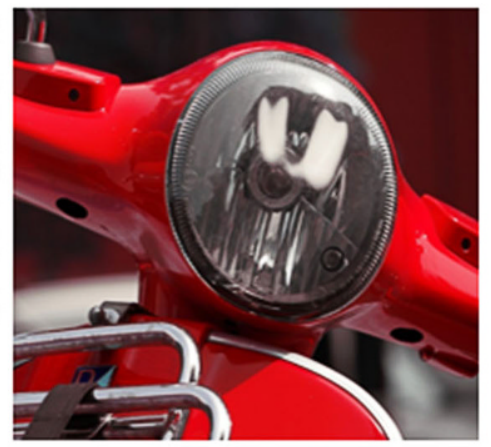

\section{Details about the sharing offer for electro scooters}

\begin{tabular}{|c|c|}
\hline Availability & $\begin{array}{l}\text { E-scooter with maximum speed of } 45 \mathrm{~km} / \mathrm{h} \\
\text { Check the availability of e-scooters via web-browser or the app in } \\
\text { advance }\end{array}$ \\
\hline Usage and return & $\begin{array}{l}\text { - Spontaneous use or reservation of e-scooters } \\
\text { - Flexible use with no pre-determined period of use } \\
\text { Pick up and return anywhere in the operation area }\end{array}$ \\
\hline Provider contact & $\begin{array}{l}\text { - Online, by phone, or e-mail } \\
\text { - Smartphone app }\end{array}$ \\
\hline Service quality & $\begin{array}{l}\text { - Friendly and easy to reach customer service } \\
\text { - E-scooters are provided in clean, fully functional condition }\end{array}$ \\
\hline Settlement & - Flexible, minute-by-minute billing \\
\hline
\end{tabular}

Fig. 6 Sharing 


\section{E-Scooter-Sharing from DB}

Deutsche Bahn starts a sharing offer for electro-

Die Bahn DB scooters

In future, the sharing offer will be available at $e$ scooter stations in many German cities. The escooters can be reserved at a desired station for any period of use in advance. Afterward, the escooters can be picked up and returned. The offer is available to everyone after a one-time registration. Because the scooters are regularly maintained, they are always in good condition and fully functional. Billing is based on the duration of usage, as a flexible tariff.

Detailed information about the offer is summarized in the table.

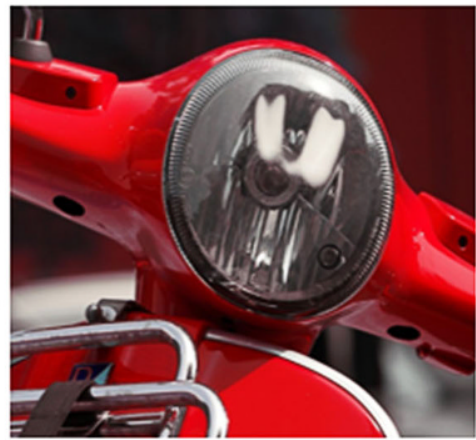

\section{Details of the sharing offer for electro scooters}

\begin{tabular}{|c|c|}
\hline Availability & $\begin{array}{l}\text { - E-scooter with maximum speed of } 45 \mathrm{~km} / \mathrm{h} \\
\text { Check the availability of e-scooters in the web-browser or via App in } \\
\text { advance }\end{array}$ \\
\hline Usage and return & $\begin{array}{l}\text { - Reservation of e-scooters by latest } 30 \text { minutes before usage } \\
\text { - Predetermined period of use } \\
\text { - Pick up and return at selected stations }\end{array}$ \\
\hline Provider contact & $\begin{array}{l}\text { - Online, by phone or e-Mail } \\
\text { - Smartphone app }\end{array}$ \\
\hline Service quality & $\begin{array}{l}\text { - Friendly and easy to reach customer service } \\
\text { - E-scooters are provided in clean and fully functional condition }\end{array}$ \\
\hline Settlement & - Flexible, $4 \mathrm{~h}$, daily, weekend, or weekly rate \\
\hline
\end{tabular}

Fig. 7 Sharewashing 


\section{E-Scooter-Renting from DB}

Deutsche Bahn starts a renting offer for electro-

Die Bahn DB scooters

In future, the renting offer will be available at $e$ scooter stations in many German cities. The escooters can be reserved at a desired station for any period of use in advance. Afterward, the escooters can be picked up and returned. The offer is available to everyone after a one-time registration. Because the scooters are regularly maintained, they are always in good condition and fully functional. Billing is based on the duration of usage, as a flexible tariff.

Detailed information about the offer is summarized in the table.

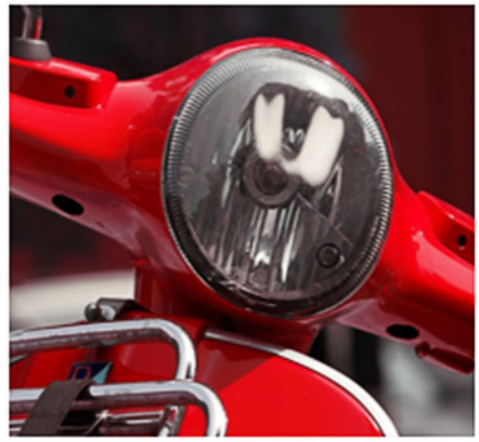

Details of the renting offer for electro scooters

$\begin{array}{ll}\text { Availability } & \begin{array}{l}\text { Check the availability of e-scooters in the web-browser or via App in } \\ \text { advance }\end{array} \\ \text { Usage and return } & \begin{array}{l}\text { - Reservation of e-scooters by latest } 30 \text { minutes before usage } \\ \text { Predetermined period of use }\end{array} \\ \text { Provider contact } & \text { - Online, by phone or e-Mail } \\ \text { Service quality } & \text { - Fmartphone app }\end{array}$

Fig. 8 Renting 


\section{Appendix 2: Study 2 and Study 3-Experimental Stimuli}

\section{Carsharing by Audi}

\section{Audi is introducing its own carsharing offer}

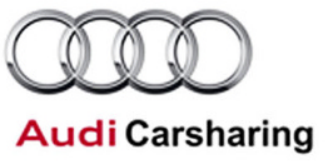

At the beginning of 2017, Audi will introduce a flexible, free-floating, carsharing service in cities with more than 400,000 residents. The offer is available to everyone after a one-time registration. Audi will supply the model $A 3^{*}$ for this service. Cars are painted the same way, clearly visible as part of the carsharing fleet. Cars can be reserved via mobile phone and RFID modules. Payment takes place after usage, via direct debit.

\section{Details of the carsharing ${ }^{\star}$ offer}

Availability

Usage and return

Provider contact

Service quality

Insurance
- In $95 \%$ of times, a car is available within a walking distance of 10 minutes

- Spontaneous use or reservation up to 20 minutes before usage is possible

- Flexible use with no pre-determined period of use

- Return of the car at a free parking lot anywhere in the city

- Online, by phone, or e-mail

- Smartphone app

- Friendly and easy to reach customer service

- Cars are provided in a clean and good condition

- Third-party insurance and all-risk insurance are inclusive

* In the e-car version we added "e-" or "electro-" as appropriate.

Fig. 9 Sharing 


\section{Carsharing by Audi}

\section{Audi is introducing its own carsharing offer}

\section{0 \\ Audi Carsharing}

At the beginning of 2017, Audi will introduce a carsharing service in cities with more than 400,000 residents. The offer is available to everyone, after a one-time registration. Audi will supply the model A3* for this service. Cars are painted the same way, clearly visible as part of the sharing fleet. At sharing stations, cars and keys can be picked up and returned. Payment is made after usage, via direct debit.

\section{Details of the carsharing ${ }^{\star}$ offer}

Availability

- Sharing stations are at railway stations and large traffic hubs

Usage and return

- Reservation at least 30 minutes before usage

- Predetermined period of use

- Return of the car at selected carsharing stations

Provider contact

- Online, by phone, or e-mail

- Smartphone app

Service quality

- Friendly and easy to reach customer service

- Cars are provided in a clean and good condition

Insurance

- Third-party insurance and all-risk insurance are inclusive

* In the e-car version we added "e-" or "electro-" as appropriate.

Fig. 10 Sharewashing 


\section{Renting by Audi}

Audi is introducing its own renting offer

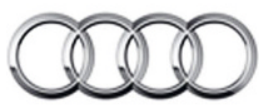

Audi Renting

At the beginning of 2017, Audi will introduce a car rental service in cities with more than 400,000 residents. The offer is available to everyone, after a one-time registration. Audi will supply the model A3* for the service. Cars are painted the same way, clearly visible as part of the rental fleet. At car rental stations, cars and keys can be picked and returned. Payment is made after usage, via direct debit.

\section{Details of the car ${ }^{\star}$ rental offer}

Availability

- Rental stations are at railway stations and large traffic hubs

Usage and return

- Reservation at least 30 minutes before usage

- Predetermined period of use

- Return of the car at selected carsharing stations

Provider contact

- Online, by phone, or e-mail

- Smartphone app

Service quality

- Friendly and easy to reach customer service

- Cars are provided in a clean and good condition

Insurance

- Third-party insurance and all-risk insurance are inclusive

* In the e-car version we added "e-" or "electro-" as appropriate.

Fig. 11 Renting 


\section{Appendix 3}

Table 12 Measurement constructs and items

\begin{tabular}{|c|c|c|}
\hline Construct & Items & Source \\
\hline $\begin{array}{l}\text { Perceived } \\
\text { Attrac- } \\
\text { tiveness }\end{array}$ & $\begin{array}{l}\text { Please indicate how strongly you agree with the following statement: } \\
\text { The presented offer fills a real need for me } \\
\text { The presented offer can give me real value }\end{array}$ & $\begin{array}{l}\text { Adapted from } \\
\text { Grewal et al. } \\
(1998)\end{array}$ \\
\hline $\begin{array}{l}\text { Information } \\
\text { Seeking }\end{array}$ & $\begin{array}{l}\text { Please indicate how strongly you agree with the following statements: } \\
\text { I would like to obtain information extensively about the presented offer } \\
\text { I would directly search for more information about the presented offer } \\
\text { I need more information about the presented offer } \\
\text { I would like to have more information about the presented offer }\end{array}$ & $\begin{array}{l}\text { Adapted from } \\
\text { van Ittersum } \\
\text { and Feinberg } \\
(2010)\end{array}$ \\
\hline $\begin{array}{l}\text { Usage } \\
\text { Intention }\end{array}$ & 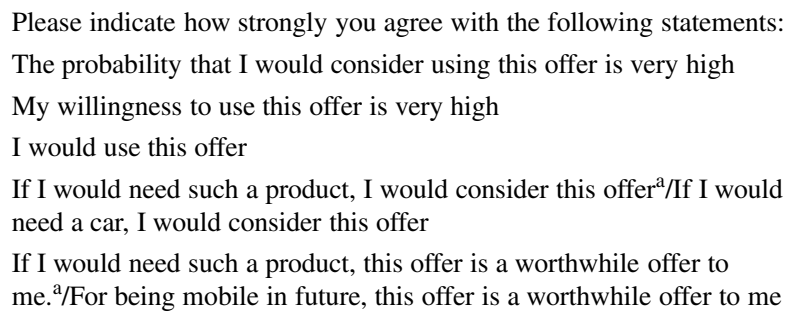 & $\begin{array}{l}\text { Adapted from } \\
\text { Grewal et al. } \\
(1998)\end{array}$ \\
\hline $\begin{array}{l}\text { Brand } \\
\text { Attitude } \\
\text { (Control) }\end{array}$ & $\begin{array}{l}\text { Please indicate how strong you agree with the following statements. } \\
\text { I evaluate the brand Audi as ... } \\
\text { Bad/good } \\
\text { Unpleasant/pleasant } \\
\text { Unreliable/reliable } \\
\text { Unlikeable/likable } \\
\text { Negative/positive }\end{array}$ & $\begin{array}{l}\text { Adapted from } \\
\text { Bergkvist and } \\
\text { Rossiter } \\
(2007)\end{array}$ \\
\hline $\begin{array}{l}\text { Attitude } \\
\text { to help } \\
\text { others } \\
\text { (Marker) }\end{array}$ & $\begin{array}{l}\text { Please indicate how strongly you agree with the following statements: } \\
\text { People should be willing to help others who are less fortunate } \\
\text { Helping troubled people with their problems is very important to me } \\
\text { People should be more charitable toward others in society } \\
\text { People in need should receive support from others }\end{array}$ & $\begin{array}{l}\text { Adapted from } \\
\text { Webb et al. } \\
(2000)\end{array}$ \\
\hline $\begin{array}{l}\text { Consumer } \\
\text { Skepti- } \\
\text { cism }\end{array}$ & $\begin{array}{l}\text { Concerning the offer, I am ... } \\
\text { Skeptical } \\
\text { Suspicious } \\
\text { Distrustful }\end{array}$ & $\begin{array}{l}\text { Adapted from } \\
\text { Babin et al. } \\
(1995)\end{array}$ \\
\hline
\end{tabular}

\footnotetext{
${ }^{\mathrm{a}}$ Item in Study 1
} 
Acknowledgements The authors thank the graduate students Mr. Krebs and Mr. Munck for their support in data collection.

Open Access This article is licensed under a Creative Commons Attribution 4.0 International License, which permits use, sharing, adaptation, distribution and reproduction in any medium or format, as long as you give appropriate credit to the original author(s) and the source, provide a link to the Creative Commons licence, and indicate if changes were made. The images or other third party material in this article are included in the article's Creative Commons licence, unless indicated otherwise in a credit line to the material. If material is not included in the article's Creative Commons licence and your intended use is not permitted by statutory regulation or exceeds the permitted use, you will need to obtain permission directly from the copyright holder. To view a copy of this licence, visit http://creativecommons.org/licenses/by/4. $0 /$.

Conflict of interest A. Lehr, M. Büttgen and S. Bartsch declare that they have no competing interests.

\section{References}

Andreassen, T.W., L. Lervik-Olsen, H. Snyder, A.C.R. van Riel, J.C. Sweeney, and Y. van Vaerenbergh. 2018. Business model innovation and value-creation. The triadic way. Journal of Service Management 29(5):883-906.

Babin, B.J., J.S. Boles, and W.R. Darden. 1995. Salesperson stereotypes, consumer emotions, and their impact on information processing. Journal of the Academy of Marketing Science 23(2):94-105.

Bardhi, F., and G.M. Eckhardt. 2012. Access-based consumption. The case of car sharing. Journal of Consumer Research 39(4):881-898.

Baumeister, C., A. Scherer, and F. v. Wangenheim. 2015. Branding access offers. The importance of product brands, ownership status, and spillover effects to parent brands. Journal of the Academy of Marketing Science 43(5):574-588.

Belk, R. 2010. Sharing. Journal of Consumer Research 36(5):715-734.

Belk, R. 2014a. Sharing versus pseudo-sharing in web 2.0. The Anthropologist 18(1):7-23.

Belk, R. 2014b. You are what you can access. Sharing and collaborative consumption online. Journal of Business Research 67(8):1595-1600.

Benoit, S., T.L. Baker, R.N. Bolton, T. Gruber, and J. Kandampully. 2017. A triadic framework for collaborative consumption (CC). Motives, activities and resources \& capabilities of actors. Journal of Business Research 79:219-227.

Bergkvist, L., and J.R. Rossiter. 2007. The predictive validity of multiple-item versus single-item measures of the same constructs. Journal of Marketing Research 44(2):175-184.

Botsman, R., and R. Rogers. 2010. What's mine is yours: The rise of collaborative consumption. New York: Harper Business.

Boyd, T.C., and C.H. Mason. 1999. The link between attractiveness of 'extrabrand' attributes and the adoption of innovations. Journal of the Academy of Marketing Science 27(3):306-319.

Brosi, P., M. Spörrle, and I.M. Welpe. 2018. Do we work hard or are we just great? The effects of organizational pride due to effort and ability on proactive behavior. Business Research 11(2):357-373.

de Bruyn, A., and G.L. Lilien. 2008. A multi-stage model of word-of-mouth influence through viral marketing. International Journal of Research in Marketing 25(3):151-163.

Büttgen, M., J. Dicenta, K. Spohrer, V. Venkatesh, R. Raman, H. Hoehle, A. De Keyser, C. Verbeeck, T.J. Zwienenberg, K.P. Jørgensen, R. Beck, O. Rikken, M. Janssen, Z. Kwee, and F. Schär. (2021). Blockchain in Service Management and Service Research - Developing a Research Agenda and Managerial Implications, Journal of Service Management Research 5(2).

car2go. 2019. More Members, More rentals. car2go has successful financial year 2018. https://www. car2go.com/media/data/germany/microsite-press/files/190110_press-release_successful-financialyear-2018.pdf. Accessed 5 Dec 2019.

CarClub. 2018. Car-Sharing vs. Car Rental. https://www.carclub.com.sg/car-sharing-rental-difference/. Accessed 25 Oct 2020.

Chang, C.-T., and Z.-H. Cheng. 2015. Tugging on heartstrings. Shopping orientation, mindset, and consumer responses to cause-related marketing. Journal of Business Ethics 127(2):337-350.

Connors, S., S. Anderson-MacDonald, and M. Thomson. 2017. Overcoming the 'window dressing' effect. Mitigating the negative effects of inherent skepticism towards corporate social responsibility. Journal of Business Ethics 145(3):599-621.

Costello, J.P., and R.W. Reczek. 2020. Providers versus platforms. Marketing communications in the sharing economy. Journal of Marketing 84(6):22-38. 
Dahlmann, D. 2016. VW stellt Carsharing-Projekt komplett ein. https://www.gruenderszene.de/automotivemobility/vw-quicar-eingestellt. Accessed 17 Jan 2018.

Demirgunes, B.K., and M.Y. Avcilar. 2017. The effect of cognitive dissonance on external information search and consumer complaint responses. International Journal of Business Administration 8(2):57-72.

Dholakia, U.M. 2001. A motivational process model of product involvement and consumer risk perception. European Journal of Marketing 35(11/12):1340-1362.

Eggert, A., L. Steinhoff, and I. Garnefeld. 2015. Managing the bright and dark sides of status endowment in hierarchical loyalty programs. Journal of Service Research 18(2):210-228.

Ellen, P.S. 2006. Building corporate associations. Consumer attributions for corporate socially responsible programs. Journal of the Academy of Marketing Science 34(2):147-157.

Ertz, M., F. Durif, and M. Arcand. 2017. An analysis of the origins of collaborative consumption and its implications for marketing. Academy of Marketing Studies Journal 21(1):1-17.

Estes, Z., L. Brotto, and B. Busacca. 2018. The value of art in marketing. An emotion-based model of how artworks in ads improve product evaluations. Journal of Business Research 85:396-405.

Field, J.M., L. Victorino, R.W. Buell, M.J. Dixon, S. Meyer Goldstein, L.J. Menor, M.E. Pullman, A.V. Roth, E. Secchi, and J.J. Zhang. 2018. Service operations. What's next? Journal of Service Management 29(1):55-97.

FleetEurope. 2019. Why mobility needs aggregator apps. https://www.fleeteurope.com/en/maas/europe/ analysis/why-mobility-needs-aggregator-apps?a $=\mathrm{JMA} 06 \& \mathrm{t} \% 5 \mathrm{~B} 0 \% 5 \mathrm{D}=\mathrm{Sixt} \& \mathrm{t} \% 5 \mathrm{~B} 1 \% 5 \mathrm{D}=\mathrm{KPMG} \&$ t\%5B2\%5D=Ride\%20hailing\&t\%5B3\%5D=Car\%20sharing\&t\%5B4\%5D=Apps\&curl=1. Accessed 10 Dec 2019.

Forehand, M.R., and S. Grier. 2003. When is honesty the best policy? The effect of stated company intent on consumer skepticism. Journal of Consumer Psychology 13(3):349-356.

Fritze, M.P., A. Marchand, A.B. Eisingerich, and M. Benkenstein. 2020. Access-based services as substitutes for material possessions. The role of psychological ownership. Journal of Service Research 23(3):368-385.

Gheorghe, G. 2017. April Rinne, World Economic Forum: How we adapt to the sharing economy will determine our success and well-being. http://www.business-review.eu/br-exclusive/april-rinne-worldeconomic-forum-how-we-adapt-to-the-sharing-economy-will-determine-our-success-and-wellbeing-152093. Accessed 18 Nov 2017.

Grewal, D., K.B. Monroe, and R. Krishnan. 1998. The effects of price-comparison advertising on buyers' perceptions of acquisition value, transaction value, and behavioral intentions. Journal of Marketing 62(2):46-59.

Gullstrand Edbring, E., M. Lehner, and O. Mont. 2016. Exploring consumer attitudes to alternative models of consumption. Motivations and barriers. Journal of Cleaner Production 123:5-15.

Hahn, R., F. Ostertag, A. Lehr, M. Büttgen, and S. Benoit. 2020. 'I like it, but I don't use it'. Impact of carsharing business models on usage intentions in the sharing economy. Business Strategy and the Environment 29(3):1404-1418.

Hair, J.F. 2010. Multivariate data analysis, 7th ed., Upper Saddle River: Pearson Prentice Hall.

Hair, J.F., G.T.M. Hult, C.M. Ringle, and M. Sarstedt. 2017. A primer on partial least squares structural equation modeling (PLS-SEM), 2nd ed., Los Angeles: Sage.

Hamari, J., M. Sjöklint, and A. Ukkonen. 2016. The sharing economy. Why people participate in collaborative consumption. Journal of the Association for Information Science and Technology 67(9):2047-2059.

Hartl, B., T. Sabitzer, E. Hofmann, and E. Penz. 2018. 'Sustainability is a nice bonus' the role of sustainability in carsharing from a consumer perspective. Journal of Cleaner Production 202:88-100.

Hayes, A.F. 2013. Introduction to mediation, moderation, and conditional process analysis: a regressionbased approach, methodology in the social sciences. New York, London: Guilford.

Hazée, S., C. Delcourt, and Y. van Vaerenbergh. 2017. Burdens of access: understanding customer barriers and barrier-attenuating practices in access-based services. Journal of Service Research 20(4):441-456.

Hazée, S., Y. van Vaerenbergh, C. Delcourt, and L. Warlop. 2019. Sharing goods? Yuck, no! An investigation of consumers' contamination concerns about access-based services. Journal of Service Research 22(3):256-271.

Heider, F. 1944. Social perception and phenomenal causality”. Psychological Review 51(6):358-374.

van Ittersum, K., and F.M. Feinberg. 2010. Cumulative timed intent. A new predictive tool for technology adoption. Journal of Marketing Research 47(5):808-822. 
Kearney. 2019. The demystification of car sharing. https://www.de.kearney.com/automotive/article?/a/thedemystification-of-car-sharing. Accessed 17 Jan 2021.

Kelley, H.H. 1973. The processes of causal attribution". American Psychologist 28(2):107-128.

Kelley, H.H., and J.L. Michela. 1980. Attribution theory and research. Annual review of psychology 31(1):457-501.

Kiel, G.C., and R.A. Layton. 1981. Dimensions of consumer information seeking behavior. Journal of Marketing Research 18(2):233-239.

Kirmani, A. 2011. Consumer use of persuasion knowledge. In Consumer insights: Findings from the behavioral research, ed. J. Alba, 63-64. : Marketing Science Inst.

Klein, J., and N. Dawar. 2004. Corporate social responsibility and consumers' attributions and brand evaluations in a product-harm crisis. International Journal of Research in Marketing 21(3):203-217.

Lagadic, M., A. Verloes, and N. Louvet. 2019. Can carsharing services be profitable? A critical review of established and developing business models. Transport Policy 77:68-78.

Lamberton, C.P., and R.L. Rose. 2012. When is ours better than mine? A framework for understanding and altering participation in commercial sharing systems. Journal of Marketing 76(4):109-125.

Lawson, S.J., M.R. Gleim, R. Perren, and J. Hwang. 2016. Freedom from ownership. An exploration of access-based consumption. Journal of Business Research 69(8):2615-2623.

Leonidou, C.N., and D. Skarmeas. 2017. Gray shades of green. Causes and consequences of green skepticism. Journal of Business Ethics 144(2):401-415.

Lindell, M.K., and D.J. Whitney. 2001. Accounting for common method variance in cross-sectional research designs". Journal of Applied Psychology 86(1):114-121.

Löhle, J. 2017. Car2go zieht sich aus der Fläche zurück. https://www.stuttgarter-nachrichten.de/inhalt. elektroautos-in-der-region-stuttgart-car2go-zieht-sich-aus-der-flaeche-zurueck.567504f5-4fa84d26-9be6-ca8f89fb5015.html. Accessed 18 Nov 2018.

Mandler, T., S. Won, and K. Kim. 2017. Consumers' cognitive and affective responses to brand origin misclassifications. Does confidence in brand origin identification matter? Journal of Business Research 80:197-209.

Marchi, A., and E.-J. Parekh. 2015. How the sharing economy can make its case. https://www.mckinsey. com/business-functions/strategy-and-corporate-finance/our-insights/how-the-sharing-economycan-make-its-case-its-case. Accessed 24 Mar 2017.

Market Insider. 2019. DGAP-News: Sixt SE: SIXT launches world's first comprehensive mobility platform in the form of a new app that includes digital car rentals, car sharing and ride hailing for its 20 million customers. https://markets.businessinsider.com/news/stocks/dgap-news-sixt-se-sixt-launchesworld-s-first-comprehensive-mobility-platform-in-the-form-of-a-new-app-that-includes-digitalcar-rentals-car-sharing-and-ride-hailing-for-its-20-million-customers-1027995930. Accessed 12 Dec 2019.

Moeller, S., and K. Wittkowski. 2010. The burdens of ownership. reasons for preferring renting. Managing Service Quality: An International Journal 20(2):176-191.

Möhlmann, M. 2015. Collaborative consumption. Determinants of satisfaction and the likelihood of using a sharing economy option again. Journal of Consumer Behaviour 14(3):193-207.

Mooney, H. 2019. Share Now: Car2Go cars to go away, fleet to rebrand after BMW merger. https:// vancouversun.com/news/local-news/share-now-car2go-cars-to-go-away-fleet-to-rebrand-afterbmw-merger. Accessed 5 Dec 2019.

Newman, J.W., and R. Staelin. 1972. Prepurchase information seeking for new cars and major household appliances. Journal of Marketing Research 9(3):249-257.

News, B.B.C. 2018. Facebook under fire in data row. http://www.bbc.com/news/technology-43461865. Accessed 28 Mar 2018.

Nyilasy, G., H. Gangadharbatla, and A. Paladino. 2014. Perceived Greenwashing. The interactive effects of green advertising and corporate environmental performance on consumer reactions. Journal of Business Ethics 125(4):693-707.

Obermiller, C., and E.R. Spangenberg. 1998. Development of a scale to measure consumer skepticism toward advertising. Journal of Consumer Psychology 7(2):159-186.

Parguel, B., F. Benoît-Moreau, and F. Larceneux. 2011. How Sustainability ratings might deter 'Greenwashing'. A closer look at ethical corporate communication. Journal of Business Ethics 102(1):15-28.

Perren, R., and R.V. Kozinets. 2018. Lateral exchange markets. How social platforms operate in a networked economy. Journal of Marketing 82(1):20-36.

Peterson, M., and T. Simkins. 2019. Consumers' processing of mindful commercial car sharing. Business Strategy and the Environment 28(3):457-465. 
Price, L.L., and R.W. Belk. 2016. Consumer ownership and sharing. Introduction to the issue. Journal of the Association for Consumer Research 1(2):193-197.

Rifon, N.J., S.M. Choi, C.S. Trimble, and H. Li. 2004. Congruence effects in sponsorship. The mediating role of sponsor credibility and consumer attributions of sponsor motive. Journal of Advertising 33(1):30-42.

Ringle, C.M., S. Wende, and J.M. Becker. 2015. SmartPLS 3. Boenningstedt: SmartPLS GmbH. http:// www.smartpls.com.

Romani, S., S. Grappi, and R.P. Bagozzi. 2016. Corporate socially responsible initiatives and their effects on consumption of green products. Journal of Business Ethics 135(2):253-264.

Roos, D., and R. Hahn. 2017. Understanding collaborative consumption:. An extension of the theory of planned behavior with value-based personal norms. Journal of Business Ethics 50(3):11.

Ruvio, A., and A. Shoham. 2007. Innovativeness, exploratory behavior, market mavenship, and opinion leadership. An empirical examination in the Asian context. Psychology and Marketing 24(8):703-722.

Sarstedt, M., J.F. Hair, C. Nitzl, C.M. Ringle, and M.C. Howard. 2020. Beyond a tandem analysis of SEM and PROCESS. Use of PLS-SEM for mediation analyses! International Journal of Market Research 62(3):288-299.

Schaefers, T., S.J. Lawson, and M. Kukar-Kinney. 2016a. How the burdens of ownership promote consumer usage of access-based services. Marketing Letters 27(3):569-577.

Schaefers, T., K. Wittkowski, S. Benoit, and R. Ferraro. 2016b. Contagious effects of customer misbehavior in access-based services. Journal of Service Research 19(1):3-21.

Sixt. 2019. SIXT share: maximum flexibility and diversity / SIXT combines car rental and car sharing. https://about.sixt.com/websites/sixt_cc/English/2999/news-details.html?newsID=1757301. Accessed 24 Jan 2021.

Skarmeas, D., and C.N. Leonidou. 2013. When consumers doubt, Watch out! The role of CSR skepticism. Journal of Business Research 66(10):1831-1838.

Statista. 2019. Autovermietung. weltweit. https://de.statista.com/outlook/270/100/autovermietung/weltweit\# market-users. Accessed 7 Dec 2019.

Statista. 2020. Carsharing-Nutzer in Deutschland. https://de-statista-com.emedien.ub.uni-muenchen.de/ statistik/daten/studie/324692/umfrage/carsharing-nutzer-in-deutschland/. Accessed 30 Oct 2020.

taz. 2017. Das neue Greenwashing. http://www.taz.de/!5380793/. Accessed 12 Dec 2017.

Tian, Q., and J.L. Robertson. 2019. How and when does perceived CSR affect employees' engagement in voluntary pro-environmental behavior? Journal of Business Ethics 155(2):399-412.

Walker, K., and F. Wan. 2012. The harm of symbolic actions and green-washing. Corporate actions and communications on environmental performance and their financial implications. Journal of Business Ethics 109(2):227-242.

Wang, L., S. Sheng, S. Wu, and K.Z. Zhou. 2017. Government role, governance mechanisms, and foreign partner opportunism in IJVs. Journal of Business Research 76:98-107.

Wanner, J., and C. Janiesch. 2019. Big data analytics in sustainability reports. An analysis based on the perceived credibility of corporate published information. Business Research 12(1):143-173.

Ward, M.K., J.K. Goodman, and J.R. Irwin. 2014. The same old song. The power of familiarity in music choice. Marketing Letters 25(1):1-11.

Webb, D.J., C.L. Green, and T.G. Brashear. 2000. Development and validation of scales to measure attitudes influencing monetary donations to charitable organizations. Journal of the Academy of Marketing Science 28(2):299-309.

Weiner, B. 2000. Attributional thoughts about consumer behavior. Journal of Consumer Research 27(3):382-387.

Wilkinson, A. 2018. Uber's 'disruption' is far from benign-but it's not too big to ban. https://www. theguardian.com/commentisfree/2017/nov/22/uber-disruption-ban-london-sadiq-khan. Accessed 22 Mar 2018.

Wruk, D., A. Oberg, J. Klutt, and I. Maurer. 2019. The presentation of self as good and right. How value propositions and business model features are linked in the sharing economy. Journal of Business Ethics 159(4):997-1021.

Wu, F., A. Samper, A.C. Morales, and G.J. Fitzsimons. 2017. It's too pretty to use! When and how enhanced product aesthetics discourage usage and lower consumption enjoyment. Journal of Consumer Research 44(3):651-672.

Yin, J., L. Qian, and A. Singhapakdi. 2016. Sharing sustainability. How values and ethics matter in consumers' adoption of public bicycle-sharing scheme. Journal of Business Ethics 149(1):313-332.

Zajonc, R.B. 1968. Attitudinal effects of mere exposure”. Journal of Personality and Social Psychology 9(2):1-27. 